\title{
Volatile organic compounds produced by the phytopathogenic bacterium Xanthomonas campestris pv. vesicatoria 85-10 \\ Teresa Weise ${ }^{1}$, Marco Kai ${ }^{1,2}$, Anja Gummesson ${ }^{3}$, Armin Troeger ${ }^{4}$, Stephan von Reu $\beta^{4,5}$, Silvia Piepenborn ${ }^{1}$, Francine Kosterka ${ }^{1}$, Martin Sklorz ${ }^{3}$, Ralf Zimmermann ${ }^{3}$, Wittko Francke ${ }^{4}$ and Birgit Piechulla ${ }^{* 1, \S}$
}

\section{Full Research Paper}

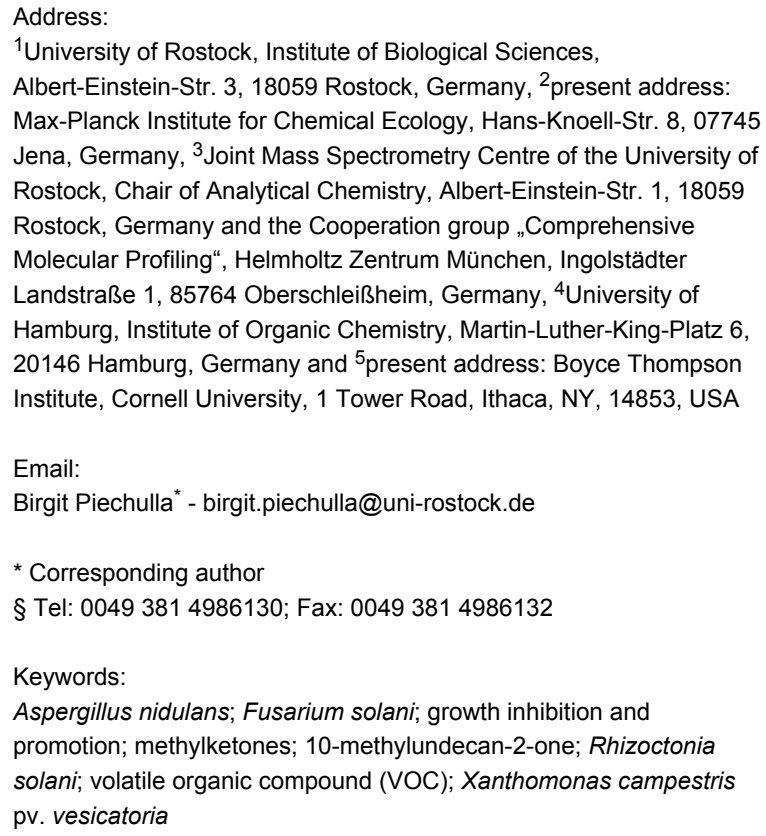

${ }^{1}$ University of Rostock, Institute of Biological Sciences, Albert-Einstein-Str. 3, 18059 Rostock, Germany, ${ }^{2}$ present address: Max-Planck Institute for Chemical Ecology, Hans-Knoell-Str. 8, 07745 Jena, Germany, ${ }^{3}$ Joint Mass Spectrometry Centre of the University of Rostock, Chair of Analytical Chemistry, Albert-Einstein-Str. 1, 18059 Rostock, Germany and the Cooperation group „Comprehensive Molecular Profiling“, Helmholtz Zentrum München, Ingolstädter Landstraße 1, 85764 Oberschleißheim, Germany, ${ }^{4}$ University of Hamburg, Institute of Organic Chemistry, Martin-Luther-King-Platz 6, 20146 Hamburg, Germany and 5 present address: Boyce Thompson Institute, Cornell University, 1 Tower Road, Ithaca, NY, 14853, USA

Email:

Birgit Piechulla* - birgit.piechulla@uni-rostock.de

* Corresponding author

§ Tel: $00493814986130 ;$ Fax: 00493814986132

Keywords:

Aspergillus nidulans; Fusarium solani; growth inhibition and promotion; methylketones; 10-methylundecan-2-one; Rhizoctonia solani; volatile organic compound (VOC); Xanthomonas campestris pv. vesicatoria

\begin{abstract}
Beilstein J. Org. Chem. 2012, 8, 579-596. doi:10.3762/bjoc. 8.65
\end{abstract}

Received: 09 February 2012

Accepted: 19 March 2012

Published: 17 April 2012

This article is part of the Thematic Series "Biosynthesis and function of secondary metabolites".

Guest Editor: J. S. Dickschat

(C) 2012 Weise et al; licensee Beilstein-Institut. License and terms: see end of document.

\begin{abstract}
Xanthomonas campestris is a phytopathogenic bacterium and causes many diseases of agricultural relevance. Volatiles were shown to be important in inter- and intraorganismic attraction and defense reactions. Recently it became apparent that also bacteria emit a plethora of volatiles, which influence other organisms such as invertebrates, plants and fungi. As a first step to study volatile-based bacterial-plant interactions, the emission profile of Xanthomonas c. pv. vesicatoria 85-10 was determined by using GC/MS and PTR-MS techniques. More than 50 compounds were emitted by this species, the majority comprising ketones and methylketones. The structure of the dominant compound, 10-methylundecan-2-one, was assigned on the basis of its analytical data, obtained by GC/MS and verified by comparison of these data with those of a synthetic reference sample. Application of commercially available decan-2-one, undecan-2-one, dodecan-2-one, and the newly synthesized 10-methylundecan-2-one in bi-partite Petri dish bioassays
\end{abstract}


revealed growth promotions in low quantities $(0.01$ to $10 \mu \mathrm{mol})$, whereas decan-2-one at $100 \mu \mathrm{mol}$ caused growth inhibitions of the fungus Rhizoctonia solani. Volatile emission profiles of the bacteria were different for growth on media (nutrient broth) with or without glucose.

\section{Introduction}

Plant surfaces are inhabited by diverse and complex communities of microorganisms, although these habitats may be hostile environments, e.g. [1-6]. Bacteria are the most dominant inhabitants, e.g., more than $10^{7}$ cells per $\mathrm{cm}^{2}$ of leaf surface are present, but also filamentous fungi and yeasts are found $[7,8]$. One of the most abundant bacterial genera in the phyllosphere is Xanthomonas; $X$. campestris is the dominant species, and at least 141 pathovars invasive against several plant species are known, including many of agricultural relevance [9]. Prominent and widespread diseases caused by Xanthomonas species include diseases such as bacterial spot on peppers and tomatoes, citrus canker, and bacterial blight disease in rice $[9,10]$. Unravelling the mechanisms for phytopathogenicity and virulence of $X$. campestris resulted in the identification of a type-three secretion system through which bacterial effector proteins enter the plant cells to interfere with cellular processes, to the benefit of the bacterium [11]. However, some plants react to the effector proteins by local cell death, a hypersensitive response, and are able to escape bacterial spreading and invasion. Apart from these cell-to-cell-based interactions, additional modes of action of $X$. campestris may influence growth of the plant directly or indirectly. Although antagonistic features of Xanthomonas spp. against fungi have been only sparsely studied, it is known that Xanthomonas competes with fungi [3]. The bacteria take up nutrients more rapidly and in larger amounts as compared to the germ tubes of fungi. This could be advantageous for Xanthomonas during competition for nutrients. Furthermore, some antagonistic activity of two Xanthomonas isolates against Verticillium dahliae was documented [12]. Since only a little or no production of lytic enzymes or siderophores could be observed, other mechanisms must exist that promote bacterial growth versus fungal growth. It was shown that 11-methyldodec-2Z-enoic acid, known as quorum-sensing signal, produced by $X$. campestris pv. campestris repressed hyphal development in Candida albicans [13], and Hogan et al. [14] concluded that either the bacteria modulate the fungal behavior or that C. albicans (or related fungi) responded to the presence of antagonistic bacteria in such a way that it was advantageous for the bacteria.

Volatiles were also shown to support and facilitate crosskingdom interactions, such as plant-insect communications as bi- and tritrophic attractions and defenses [15]. For example, volatiles emitted by vegetative plant tissues suppress the growth of microorganisms, both in the case of bacteria and fungi [16-
19]. Recently, a new field of interest emerged, when it became apparent that also bacteria emit a plethora of volatiles, which may influence other organisms, such as invertebrates, plants and fungi $[20,21]$. There is increasing information about those volatiles emitted by bacteria, especially rhizobacteria, e.g., [22$25]$, which influence the growth of fungi $[22,23,26,27]$. In most cases the bacterial volatiles showed inhibitory activities (reviewed in [20]). We, therefore, hypothesized that volatile compounds emitted by Xanthomonas campestris pv. vesicatoria 85-10 may also play a role as antagonistic weapons against competitive fungi. As a first approach in our investigations, we analysed the profiles of its volatiles. Only two volatile organic compounds released by $X$. campestris have so far been described: 11-methyldodec-2Z-enoic acid [13] and $\gamma$-butyrolactone [28]. To extend this preliminary information we carried out GC/MS and proton transfer reaction (PTR)-MS analyses with $X$. c. pv. vesicatoria 85-10. In addition, we aimed at structure elucidation and on temporal variation of profiles of volatiles produced upon growth on different media.

\section{Results and Discussion Effect of Xanthomonas campestris pv. vesi- catoria volatiles on fungal growth}

So far neglected in former investigations was the possibility that volatiles emitted from $X$. c. pv. vesicatoria 85-10 may influence plant growth directly or indirectly, e.g., through fungi. As a first step to investigate whether Xanthomonas volatiles effect other organisms, three fungi, Aspergillus nidulans, Fusarium solani and Rhizoctonia solani, were cocultivated with $X$. c. pv. vesicatoria 85-10 in compartmentalized Petri dishes (Figure 1). This ensures that only volatiles can diffuse between the compartments to act on the fungal test organisms. Since it is known that growth media influence the pattern of bacterial volatiles [29], nutrient broth with and without the addition of glucose, NBG and NB, respectively, were investigated. Figure 1A-D demonstrates the effects of Xanthomonas volatiles on $R$. solani in such a culture system. In the absence of bacteria the fungus exhibits circular mycelium growth (control, Figure 1A and Figure 1C), while growth was retarded when $X$. c. pv. vesicatoria 85-10 was growing in the other compartment (Figure 1B and Figure 1D). Growth of $R$. solani was more inhibited when $X$. c. pv. vesicatoria 85-10 grew on NB compared to less inhibition when it was grown on NBG $(98 \%$ vs 55\%, Figure 1B and Figure 1D, respectively). The same tendency was observed for the growth of $A$. nidulans and $F$. solani. 


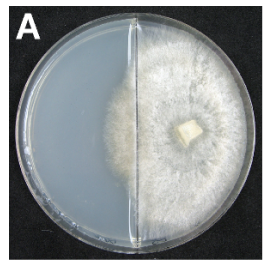

control

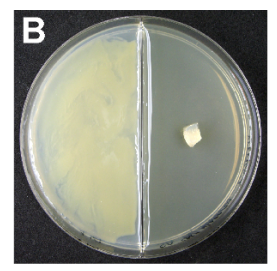

NB

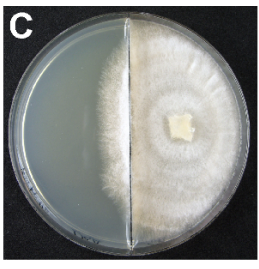

control

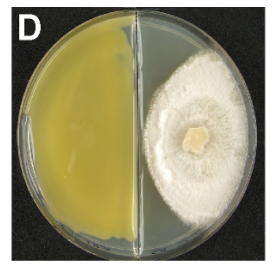

NBG

$\mathbf{E}$

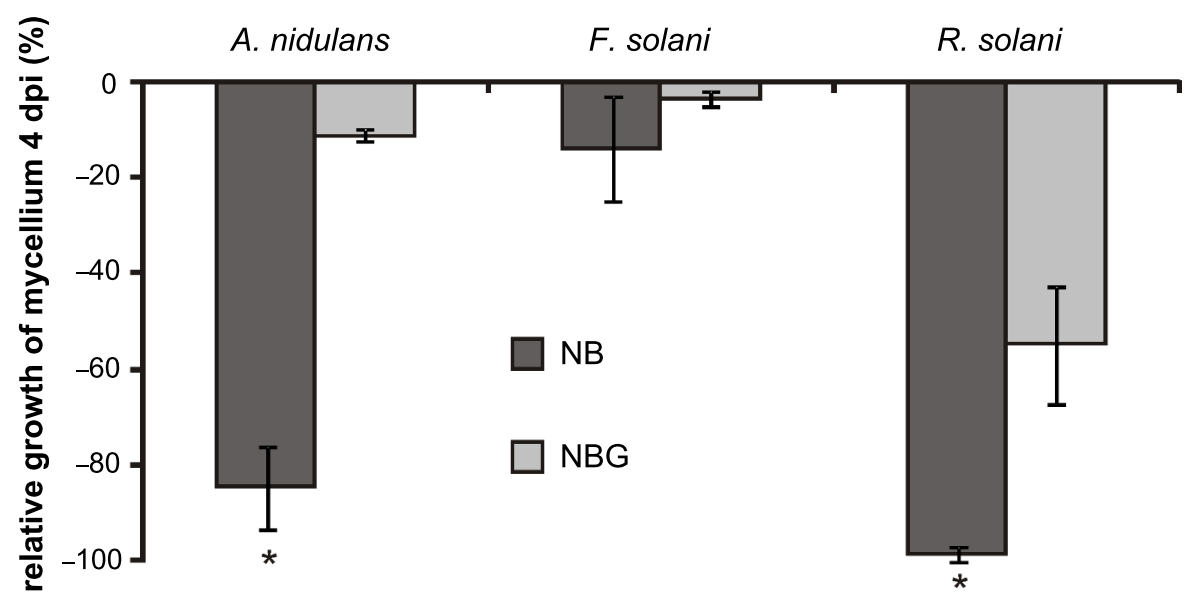

Figure 1: Cocultivation of Xanthomonas campestris pv. vesicatoria 85-10 with three fungi on different media. (A) Control experiment: Cultivation of Rhizoctonia solani on NB (day 4). (B) Cocultivation of X. c. pv. vesicatoria 85-10 on NB with Rhizoctonia solani (day 4). (C) Control experiment: Cultivation of Rhizoctonia solani on NBG (day 4). (D) Cocultivation of X. c. pv. vesicatoria 85-10 on NBG with Rhizoctonia solani (day 4). (E) Quantification of the inhibition of fungal mycelium growth during cocultivation with $X$. c. pv. vesicatoria 85-10, either grown on NB (black column) or NBG (grey column). Fungi: Aspergillus nidulans, Fusarium solani and Rhizoctonia solani. (4 dpi: four days after inoculation; NBG: nutrient broth (NB) II agar plus $1.1 \%$ glucose; *: growth significantly different compared to the control, $p<0.01$ according to t-test).

When $X$. c. pv. vesicatoria 85-10 grew on NB, A. nidulans was inhibited by $85 \%$ and $F$. solani by $14 \%$, while the inhibition of both fungi on NBG was only $11 \%$ and $3.5 \%$, respectively. The inhibitory potential of $X . c$. pv. vesicatoria 85-10 volatiles on fungi was less pronounced when the bacteria grew on glucosecontaining media (Figure 1E), indicating that growth suppression depended on the supplied nutrient source. Fiddaman and Rossall [29] described similar results, since the addition of D-glucose but not L-glucose lead to the formation of inhibitory volatiles by Bacillus subtilis. The milder inhibitory potential of $X$. c. pv. vesicatoria 85-10 growing on NBG, may be explained by the suggestions that (i) inhibitory volatiles were produced in higher amounts when grown on NB medium, (ii) inhibitory volatiles were only produced in the peptone-rich NB medium, (iii) glucose suppressed the production of inhibitory volatiles, for example through catabolite repression, or (iv) the emission of inhibitory volatiles was delayed.

Interestingly, Fusarium solani was only weakly influenced by the volatiles of $X . c$. pv. vesicatoria 85-10, indicating species- specific reactions. Similar results were obtained when ten different rhizobacteria were tested with various fungi [27]. Most of the tested fungi, including $R$. solani, Verticillium dahliae, Paecilomyces carneus and Sclerotinia sclerotiorum were strongly inhibited by the rhizobacteria (Serratia spp., Pseudomonas spp., Stenotrophomonas spp.), and only F. solani appeared to be resistant against the bacterial volatiles. Also Muscodor albus volatiles only partially influence the growth of $F$. solani, while other fungi are much more severely inhibited [30]. Bacterial volatiles may also directly influence plant growth. Arabidopsis thaliana and Physcomitrella patens were exposed to mixtures of volatiles emitted by various bacteria. Depending on the bacterial species or experimental setup, either promotion or inhibition of plant growth was observed [25,27,31-35]. Individual compounds such as acetoin and 2,3butanediol acted as plant-growth-promoting agents [31], while dimethyl disulfide and 2-phenylethanol inhibited plant growth $[34,36]$. The inhibitory potential of volatiles of different Xanthomonas campestris species/isolates on Caenorhabditis elegans and on bacteria was also shown [20,37]. 


\section{Volatile emissions of Xanthomonas campestris pv. vesicatoria 85-10 GC/MS analysis of volatiles released by $X$. c. pv. vesicatoria $85-10$}

The volatiles emitted by $X . c$. pv. vesicatoria $85-10$ showed strong effects on the tested fungi (Figure 1). Therefore, it was interesting to carry out investigations on the qualitative and quantitative profiles of volatiles produced by $X . c$. pv. vesicatoria 85-10. Samples of volatiles were obtained by growing the bacteria in $10 \mathrm{~L}$ of liquid medium and trapping the volatiles on SuperQ. Upon application of GC/MS, more than $50 \mathrm{com}$ pounds were identified among a large number of components present in only very small amounts (Figure 2, Figure 3, Table 1). Contaminants (see Table 1) are marked in Figure 2. The scent released by $X . c$. pv. vesicatoria $85-10$ was shown to be particularly rich in ketones and corresponding alcohols. In addition to straight-chain methylketones from hexan-2-one (compound 1 in Figure 3 and Table 1) to pentadecan-2-one (50), several branched-chain methylketones could be identified (Figure 3, Table 1). The volatiles were found to be largely dominated by a substance (Figure 2, compound 34) showing a mass spectrum that was very similar to that of dodecan-2-one. A slightly later-eluting minor component furnished an almost identical mass spectrum. As both compounds eluted between undecan-2-one (31) and dodecan-2-one (38) (small amounts of which were found to be present among the natural volatiles), retention indices with methylketones as reference standards were calculated. Corresponding data published for methylbranched hydrocarbons and increment calculations strongly suggested iso-branching for the main compound and anteisobranching for the later-eluting isomer [38-40]. In fact, mass spectra and retention times (co-injection) of 10-methylundecan2-one (34) and 9-methylundecan-2-one (35) synthesized in our lab (Scheme 1) matched those of the respective natural products. Small amounts of the corresponding alcohols, 10-methylundecan-2-ol (36) and 9-methylundecan-2-ol (37) (stereochemistry not determined) were also detected by GC/MS and co-injection. As the headspace volatiles contained a continuous row of homologous straight-chain methylketones, identification of additional compounds with similar structures was largely facilitated: the unbranched ketones were found to be always accompanied by the iso-branched isomers and in some cases also by the anteiso-branched ones. Corresponding methylcarbinols could also be detected. The position of the double bond in a pentadecen-2-one (49), a member of the identified suite of methylketones, remained unassigned.

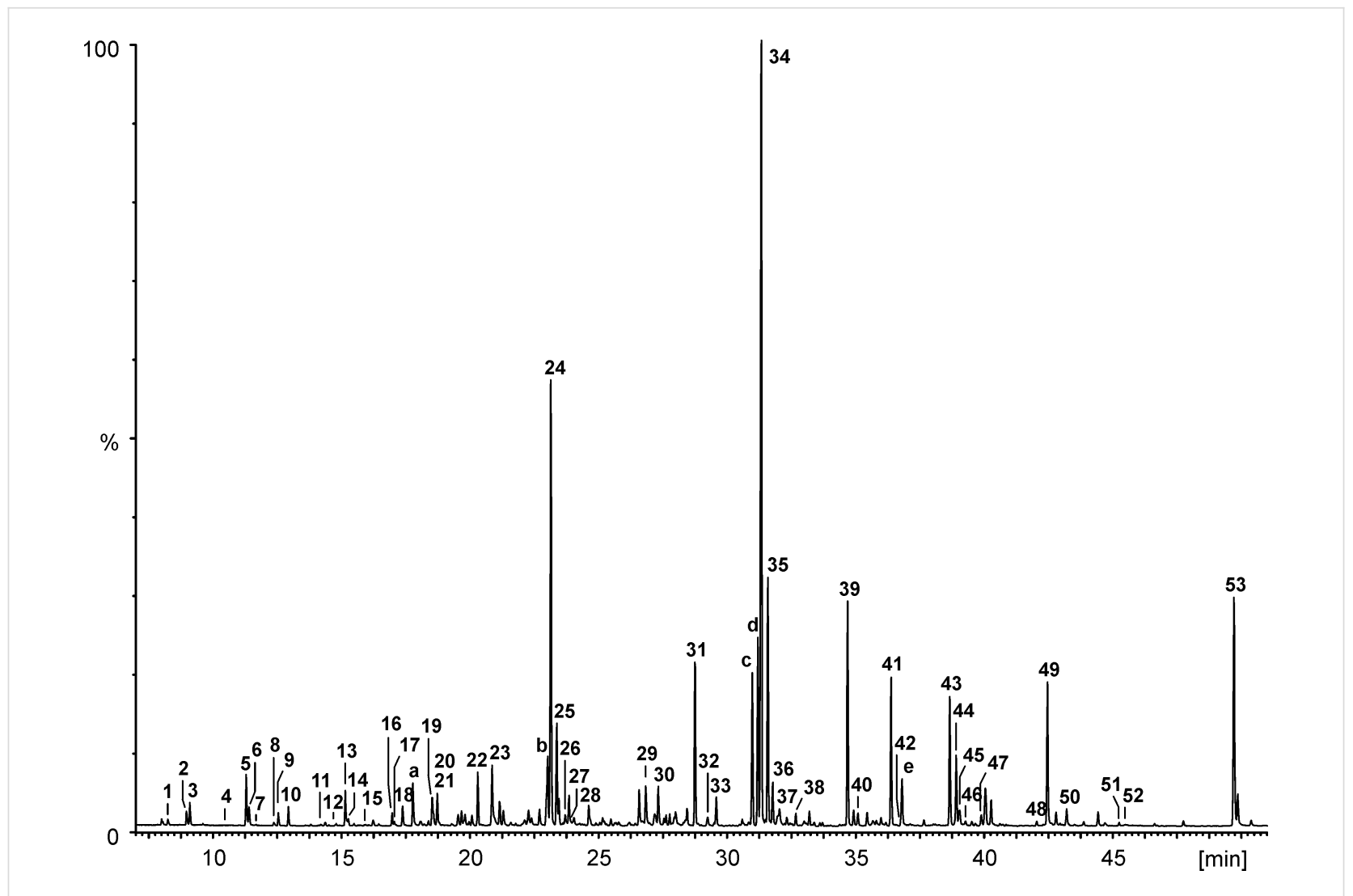

Figure 2: GC/MS-chromatogram (total ion current) of the headspace of $X$. c. pv. vesicatoria $85-10$ grown in $10 \mathrm{~L}$ liquid nutrient broth without glucose. Compound labels are the same throughout this paper. 


$$
\begin{aligned}
1: n=1 \\
7: n=2 \\
15: n=3 \\
22: n=4 \\
28: n=5 \\
31: n=6 \\
38: n=7 \\
41: n=8 \\
50: n=10
\end{aligned}
$$<smiles>CC(=O)CCC(C)C</smiles>

4: $n=1$

11: $n=2$

21: $n=3$

24: $n=4$

30: $n=5$

34: $n=6$

40: $n=7$

43: $n=8$

48: $n=9$

51: $n=10$<smiles>CCC(C)CC(C)=O</smiles>

12: $n=2$

25: $n=4$

35: $n=6$

44: $n=8$

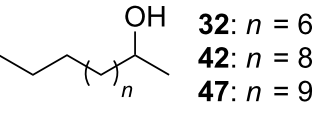<smiles>CC(C)CCCC(C)O</smiles>

26: $n=4$

36: $n=6$

45: $n=8$

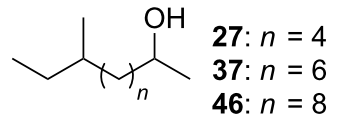<smiles>[R]C(=O)O[13C]([14CH3])[13C]([R])C</smiles>

$n=1, \mathrm{R}=\mathrm{Me}, \mathrm{R}^{\prime}=\mathrm{Me}$ 5: $n=1, \mathrm{R}=\mathrm{Et}, \mathrm{R}^{\prime}=\mathrm{Me}$ 6: $n=2, \mathrm{R}=\mathrm{Me}, \mathrm{R}^{\prime}=\mathrm{Me}$ 9: $n=1, \mathrm{R}=\mathrm{Me}, \mathrm{R}^{\prime}=\mathrm{Et}$

13: $n=1, \mathrm{R}=\mathrm{Et}, \mathrm{R}^{\prime}=\mathrm{Et}$

14: $n=2, \mathrm{R}=\mathrm{Me}, \mathrm{R}^{\prime}=\mathrm{Et}$

19: $n=2, \mathrm{R}=\mathrm{Me}, \mathrm{R}^{\prime}=\mathrm{iBu}$<smiles>CC(=O)CCC=C(C)CCC=C(C)C</smiles><smiles>CCCCCCOC(C)=O</smiles>
17

\begin{tabular}{|c|c|c|c|c|}
\hline compound & $t_{\mathrm{R}}[\mathrm{min}]$ & retention index I & rel. area [\%] & compound \\
\hline 1 & 8.23 & 778 & 0.7 & hexan-2-one \\
\hline 2 & 8.96 & 795 & 1.6 & 2-methylpropyl acetate \\
\hline 3 & 9.10 & 798 & 2.5 & n-octane \\
\hline 4 & 10.50 & 830 & $\operatorname{tr}$ & 5-methylhexan-2-one \\
\hline 5 & 11.28 & 848 & 5.4 & 2-methylbutyl acetate \\
\hline 6 & 11.40 & 851 & 2.4 & 3-methylbutyl acetate \\
\hline 7 & 11.67 & 857 & 0.2 & heptan-2-one \\
\hline 8 & 12.36 & 873 & 0.4 & 2,5-dimethylpyrazine \\
\hline 9 & 12.53 & 877 & 1.4 & 2-methylpropyl propionate \\
\hline 10 & 12.92 & 886 & 2.0 & $n$-nonane \\
\hline 11 & 14.36 & 919 & 0.5 & 6-methylheptan-2-one \\
\hline 12 & 14.78 & 929 & $\operatorname{tr}$ & 5-methylheptan-2-one \\
\hline 13 & 15.14 & 938 & 3.9 & 2-methylbutyl propionate \\
\hline 14 & 15.26 & 940 & 0.7 & 3-methylbutyl propionate \\
\hline 15 & 15.88 & 955 & $\operatorname{tr}$ & octan-2-one \\
\hline 16 & 16.22 & 963 & 0.9 & 2,3,5-trimethylpyrazine \\
\hline 17 & 16.97 & 981 & 1.3 & hexyl acetate \\
\hline 18 & 17.37 & 990 & 2.5 & benzylalcohol \\
\hline 19 & 18.51 & 1018 & 4.0 & 3-methylbutyl 3-methylbutyrate \\
\hline 20 & 18.71 & 1022 & 3.7 & acetophenone \\
\hline 21 & 18.71 & 1022 & $\operatorname{tr}$ & 7-methyloctan-2-one \\
\hline 22 & 20.29 & 1061 & 5.6 & nonan-2-one \\
\hline 23 & 20.85 & 1074 & 8.4 & 2-phenylethanol \\
\hline 24 & 23.13 & 1131 & 52.8 & 8-methylnonan-2-one \\
\hline 25 & 23.37 & 1137 & 11.6 & 7-methylnonan-2-one \\
\hline 26 & 23.69 & 1145 & 1.4 & 8-methylnonan-2-ol \\
\hline 27 & 23.99 & 1152 & $\operatorname{tr}$ & 7-methylnonan-2-ol \\
\hline
\end{tabular}
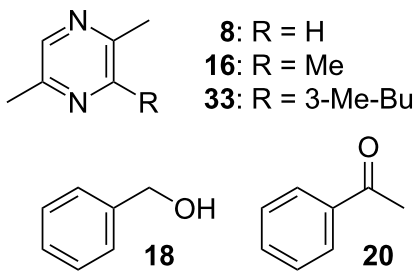<smiles>CC(=O)OCCc1ccccc1</smiles>

Figure 3: Structures of compounds emitted by Xanthomonas campestris pv. vesicatoria $85-10$. Compound labels are the same throughout this paper

Table 1: GC/MS analysis of Super-Q trapped volatiles emitted by Xanthomonas campestris pv. vesicatoria $85-10$ grown in $10 \mathrm{~L}$ nutrient broth without glucose. Compound labels are the same throughout this paper. 
Table 1: GC/MS analysis of Super-Q trapped volatiles emitted by Xanthomonas campestris pv. vesicatoria $85-10$ grown in $10 \mathrm{~L}$ nutrient broth without glucose. Compound labels are the same throughout this paper. (continued)

\begin{tabular}{|c|c|c|c|c|}
\hline 28 & 24.60 & 1168 & 2.9 & decan-2-one \\
\hline 29 & 26.82 & 1224 & 5.5 & 2-phenylethyl acetate \\
\hline 30 & 27.31 & 1237 & 4.9 & 9-methyldecan-2-one \\
\hline 31 & 28.73 & 1274 & 19.7 & undecan-2-one \\
\hline 32 & 29.23 & 1287 & 1.4 & undecan-2-ol \\
\hline 33 & 29.56 & 1296 & 3.7 & 3,6-dimethyl-2-(3-methylbutyl)pyrazine \\
\hline 34 & 31.32 & 1344 & 100.0 & 10-methylundecan-2-one \\
\hline 35 & 31.58 & 1351 & 28.3 & 9-methylundecan-2-one \\
\hline 36 & 31.76 & 1356 & 4.9 & 10-methylundecan-2-ol \\
\hline 37 & 32.02 & 1363 & 4.0 & 9-methyundecan-2-ol \\
\hline 38 & 32.66 & 1380 & 1.4 & dodecan-2-one \\
\hline 39 & 34.68 & 1437 & 25.0 & geranylacetone \\
\hline 40 & 35.08 & 1448 & 1.7 & 11-methyldodecan-2-one \\
\hline 41 & 36.37 & 1485 & 17.5 & tridecan-2-one \\
\hline 42 & 36.76 & 1496 & $\operatorname{tr}$ & tridecan-2-ol \\
\hline 43 & 38.64 & 1552 & 15.7 & 12-methyltridecan-2-one \\
\hline 44 & 38.89 & 1559 & 8.8 & 11-methyltridecan-2-one \\
\hline 45 & 39.03 & 1563 & 3.0 & 12-methyltridecan-2-ol \\
\hline 46 & 39.27 & 1570 & 0.7 & 11-methyltridecan-2-ol \\
\hline 47 & 39.87 & 1589 & 1.4 & tetradecan-2-ol \\
\hline 48 & 42.02 & 1655 & 0.6 & 13-methyltetradecan-2-one \\
\hline 49 & 42.45 & 1668 & 17.7 & pentadecen-2-one \\
\hline 50 & 43.19 & 1691 & 2.1 & pentadecan-2-one \\
\hline 51 & 45.24 & 1757 & 0.5 & 14-methylpentadecan-2-one \\
\hline 52 & 45.48 & 1765 & 0.4 & 13-methylpentadecan-2-one \\
\hline 53 & 49.69 & 1907 & 29.8 & terpenoid? \\
\hline \multicolumn{5}{|c|}{ contaminants, also in blank } \\
\hline $\mathbf{a}$ & 17.76 & 1000 & 5.1 & 2-ethylhexanol \\
\hline b & 23.01 & 1128 & 8.8 & 2-ethylhexyl acetate \\
\hline c & 30.97 & 1334 & 17.8 & hydrocarbon \\
\hline d & 31.19 & 1340 & 20.5 & hydrocarbon \\
\hline e & 36.79 & 1497 & 6.7 & 2,4-bis-tert-butylphenol \\
\hline
\end{tabular}

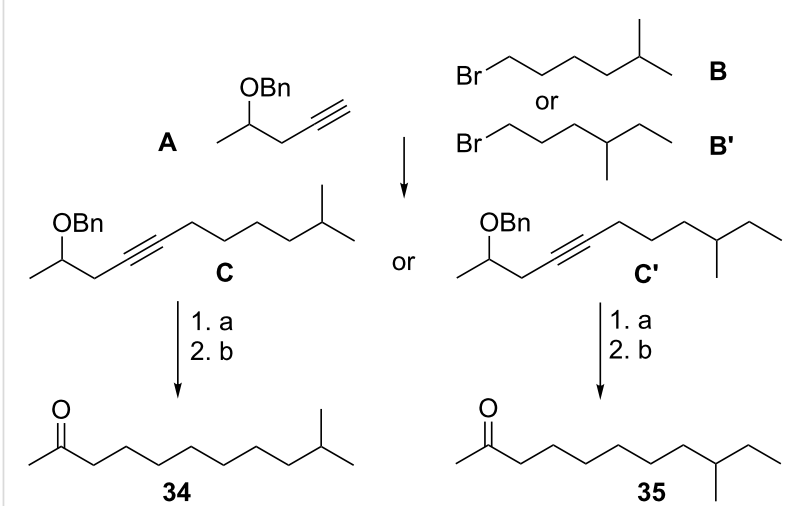

a: $\mathrm{H}_{2}$ /cat.; b: PDC

Scheme 1: Synthesis of 10-methylundecan-2-one (34) and 9-methylundecan-2-one (35).
Some of the identified ketones released by $X$. c. pv. vesicatoria 85-10 were known to be emitted by other bacteria, e.g., undecan-2-one (31) was emitted from Serratia sp. 2675, Pseudomanas fluorescens, $P$. chlororaphis, $P$. aurantiaca and $P$. corrugata $[22,41]$. Dodecan-2-one (38) was found among the volatiles of Serratia strains [41], and decan-2-one (28) was released by an epilithic cyanobacterial biofilm of Rivularia sp. and Calothrix parietina [42]. The main component among the volatile compounds released by $X$. c. pv. vesicatoria 85-10, namely 10-methylundecan-2-one (34), has been reported from plants [43-46] and bacteria, e.g., from the myxobacterium Stigmatella aurantiaca and arctic bacteria of the cytophagaflavobacterium-bacteroides group $[47,48]$. In some of these bacteria a pattern of methylketones similar to that of $X$. c. pv. vesicatoria 85-10 was found: A continuous row of homologous straight-chain methylketones accompanied by iso-branched isomers, showing 10-methylundecan-2-one (34) as a major 
component. To the best of our knowledge, the isomeric 9-methylundecan-2-one (35) has not been identified from a natural source before.

\section{Possible biosynthesis of methylketones found in Xanthomonas campestris pv. vesicatoria 85-10}

While odd-numbered, unbranched methylketones are clearly biosynthesized from straight-chain even-numbered fatty acids originating from the acetate pool, the biosynthesis of evennumbered congeners may start from propionate, a C3-unit. Consequently, odd-numbered fatty acids will yield evennumbered straight-chain methylketones. Leucine or valine may serve as the starters for the biosyntheses of iso-branched compounds [47-49], which, in this case, is supported by the presence of three esters of 3-methylbutanol and one of 2-methylbutanol. Similarly, iso-leucine (its involvement in biosynthesis being supported by the presence of esters of 2-methylbutanol) will give rise to anteiso-branching. However, due to the general principles of chain elongation with acetate/malonate units, in $X$. c. pv. vesicatoria 85-10 the corresponding methylketones showed an odd number of carbons along the chain. Conse- quently, the anteiso-branched isomers of compounds 21, 30, 40, and 48 (Table 1) were absent among the natural volatiles.

It is interesting to note that 10 -methylundecan-2-one (34), the main component among the less volatile compounds emitted by $X$. c. pv. vesicatoria 85-10, shows a close biogenetic relation to 11-methyldodec-2Z-enoic acid (compound $\mathbf{V}$ in Scheme 2), which has been described earlier as a metabolite produced by Xanthomonas [13]. Possible biogenetic pathways to the two compounds are shown in Scheme 2. Chain elongation of 3-methylbutyryl-SCoA (I), produced from leucine, will give rise to the formation of $(\omega-1)$-methylcarboxylic acids [47,50], and 10-methylundecan-2-one (34) may be either a degradation product of a longer branched-chain carboxylic acid or formed during an anabolic process. In any case, 11-methyl-3-oxodecanoyl-SCoA (III) will be the key compound in the formation of 34. Starting from $\mathbf{I}$, three complete cycles of chain elongation with malonyl-SCoA produces 9-methyldecanoyl-SCoA (II), which will yield III upon condensation with another malonyl-SCoA. After hydrolysis and decarboxylation, III will directly form 34. On the other hand, reduction of III would<smiles>CC(C)CCCCCCCC=CC(=O)OC(C)(C)C</smiles> 
furnish IV, and subsequent elimination of water would lead to $\mathbf{V}$, the immediate precursor of 11-methyldodec-2Z-enoic acid. However, $\mathbf{V}$ may also be formed upon dehydrogenation of 11-methyldodecanoyl-SCoA (VI), which, in turn, may be produced by chain shortening of 13-methyltetradecanoyl-SCoA. Further steps during $\beta$-oxidation will afford III via IV.

With the exception of 8-methylnonan-2-one (24), an important component of the female-produced sex pheromone of the desert spider Agelenopsis aperta [51], no significant biological activities have yet been reported for the identified branched methylketones and methylcarbinols.

\section{Various other volatiles are present in the profile of X. c. pv. vesicatoria $85-10$}

In addition to these methylketones and methylcarbinols, trace amounts of esters, such as 3-methylbutyl acetate (6) and 3-methylbutyl propionate (14), and the corresponding 2-methylbutyl esters $\mathbf{5}$ and $\mathbf{1 3}$ as well as 3-methylbutyl 3-methylbutyrate (19) could be identified. Trace amounts of benzylalcohol (18), acetophenone (20) and 2-phenylethanol (23) and its acetate (29) along with the three alkylated pyrazines $\mathbf{8}, \mathbf{1 6}, 33$ were the only aromatic components found in the bouquet, while geranylacetone (39) and a later-eluting yet unidentified compound, showing a mass spectrum somewhat resembling that of farnesylacetone, represented terpenoid structures among the volatiles produced by $X$. c. pv. vesicatoria 85-10.

\section{PTR-MS of highly volatile compounds released by X. c. pv. vesicatoria $85-10$}

In our previous studies it became evident that the analysis of volatile profiles by GC/MS has its technical limitations for the detection of highly volatile compounds [34,52]. To extend the spectrum of volatiles of $X$. c. pv. vesicatoria 85-10, proton transfer reaction mass spectrometry (PTR-MS) was additionally used. The analyses of volatiles emitted by $X . c$. pv. vesicatoria 85-10 were performed after three days of incubation on NB and NBG in Petri dishes (Figure 4A and Figure 4B, respectively). At least $27 \mathrm{~m} / \mathrm{z}$ values were found in the mass range between 30 and 250 with signals that were significantly enhanced ( $5 \%$ confidence level) compared to those of the blank control samples. If the proton affinity of an analyte molecule is higher than the one of $\mathrm{H}_{3} \mathrm{O}^{+}$the proton transfer reaction is more or less quantitative (quasi-first-order reaction kinetics). Thus the detection efficiency of compounds is rather independent of the nature of the analyzed molecule [53] and the signal obtained by normalization of the measured count rate to the primary ion count rate is roughly proportional to the concentration. The headspace concentrations measured by online PTR-MS during the incubation experiments cover about four orders of magnitude. The most abundant $m / z$ values $(\mathrm{M}+\mathrm{H})^{+}$were $59,30,33$,
41, 43, 57, 71, 73 and higher masses such as 157, 171 and 185 (Figure 4). As PTR-MS only provides molecular mass information, an unambiguous structure elucidation is impossible. However, the tentative assignments of some volatiles are strongly supported by the results obtained during GC/MS analysis (Figure 2, Table 1). The intensive signal at $\mathrm{m} / \mathrm{z} 157$ may be attributed to the sum of decan-2-one (28), 7-methylnonan-2-one (25) and 8-methylnonan-2-one (24); that at $\mathrm{m} / \mathrm{z}$ 171 to the sum of undecan-2-one (31) and 9-methyldecan-2-one (30); and that at $\mathrm{m} / \mathrm{z} 185$ to the sum of dodecan-2-one (38), 9-methylundecan-2-one (35) and 10-methylundecan-2-one (34). As the instrument is tuned to maximum sensitivity, even the soft ionization by $\mathrm{H}_{3} \mathrm{O}^{+}$could lead to some fragmentation due to the relatively high setting of the extraction/drift-tube voltages. Therefore, the $m / z$ values of $41,43,57,71$, especially, may be fragments of short-chain alkylketones and aldehydes, as reported by Blake et al. in 2006 [54].

\section{Changes in the compositions of headspace volatiles of Xanthomonas campestris pv. vesicatoria 85-10 during growth on different media}

Different intensities of reactions of the three tested fungi were observed when $X$. c. pv. vesicatoria 85-10 was either grown on NB or NBG (Figure 1). To trace this phenomenon, we applied solid-phase micro-extraction (SPME)-GC/MS as well as PTR-MS to monitor the patterns of headspace volatiles under two different growth conditions as well as at two different time points. The profiles of volatiles produced by $X . c$. pv. vesicatoria 85-10 growing on agar composed of NB and NBG were investigated at day 3 and day 6 after inoculation (Figure 5). A complex pattern of volatiles could be detected when $X$. c. pv. vesicatoria 85-10 was grown on the NB medium (Figure 5A). The pattern did not change much between day 3 and day 6 (Figure 5A and Figure 5C, Table 2). The volatile profile of $X$. c. pv. vesicatoria 85-10 grown on the NBG medium (day 3) proved to be simpler, both with respect to qualitative and quantitative composition, since only a few compounds could be traced (Figure 5B, Table 2). Interestingly, the number of detectable compounds increased after six days on NBG (Figure 5D, Table 2). By comparison of the bouquets released by $X . c$. pv. vesicatoria 85-10 growing on NB and NBG, only three overlapping compounds above a threshold level of $2 \times 10^{6}$ were observed at day 3 , whereas during continued incubation the compositions of bacterial volatiles became more alike, since eight compounds appeared in both chromatograms (Figure 5E, Table 2). This observation suggested a delay of volatile emission for $X$. c. pv. vesicatoria 85-10 grown on NBG. Two scenarios may explain this observation: (i) catabolite repression by glucose inhibited the synthesis of certain volatiles; or (ii) the easily accessible glucose was catabolized before other components of the medium were utilized. 

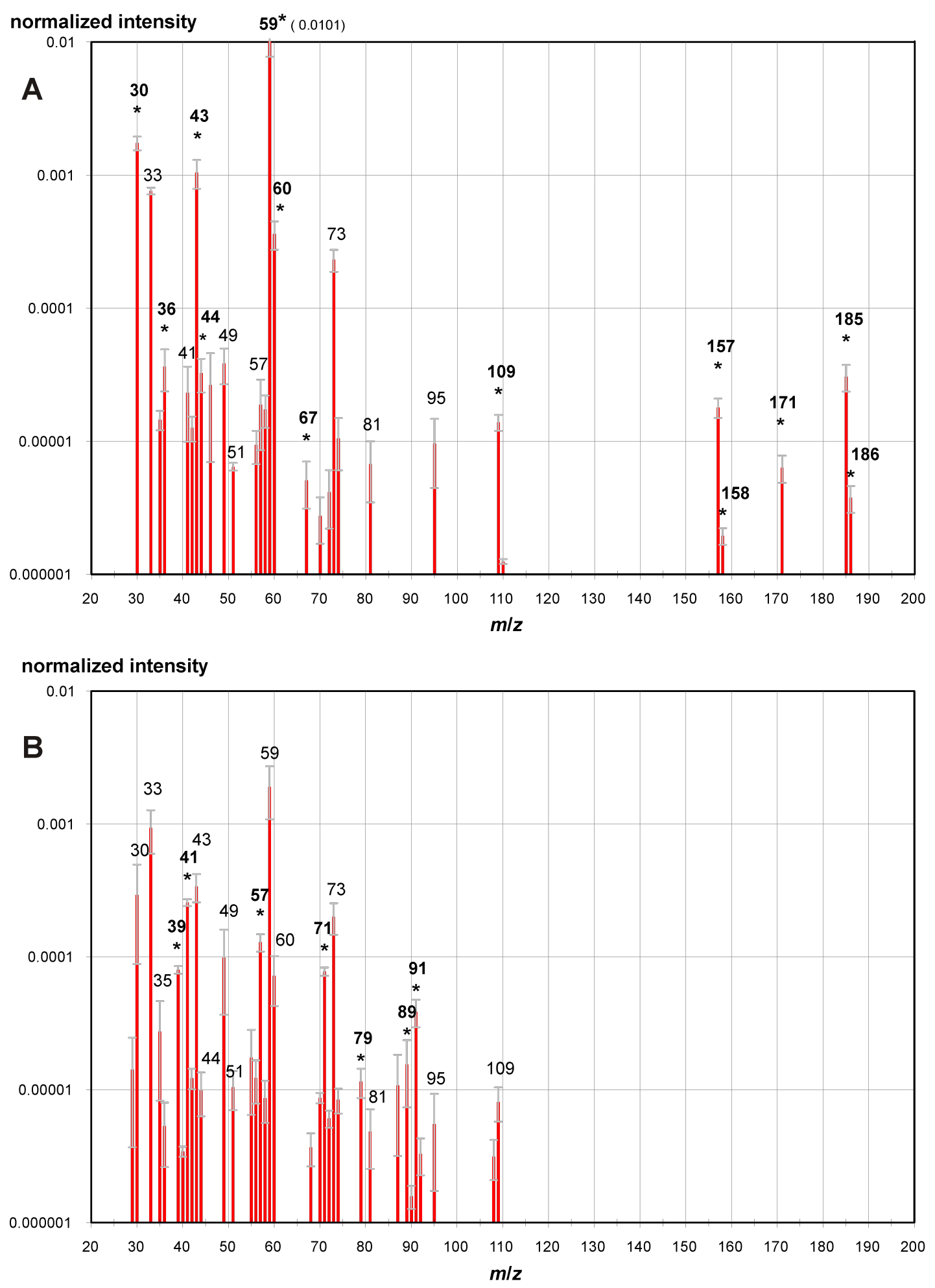

Figure 4: PTR-MS mass spectra of Xanthomonas campestris pv. vesicatoria 85-10 volatiles after three days of incubation. (A) PTR-MS profile scan of headspace volatiles of $X$. c. pv. vesicatoria 85-10 growing in a Petri dish with NB. (B) PTR-MS profile scan of headspace volatiles of $X$. c. pv. vesicatoria 85-10 growing in a Petri dish with NBG. Spectra are normalized to the primary ion signal $\left(\mathrm{H}_{3} \mathrm{O}^{+}\right)$and are blank corrected (i.e., spectra recorded from the respective media without bacteria are subtracted). Signals that are significantly influenced by the growth media (5\% confidence level) are labeled by *. Only significant signals (mean subtracted by standard deviation) higher than $10^{-6}$ are shown and a log-scale on the ordinate axis is used. Note that missing signals therefore do not necessarily indicate zero concentration but may also be due to the variance of the sample or a blank signal higher than the mean value. 
A

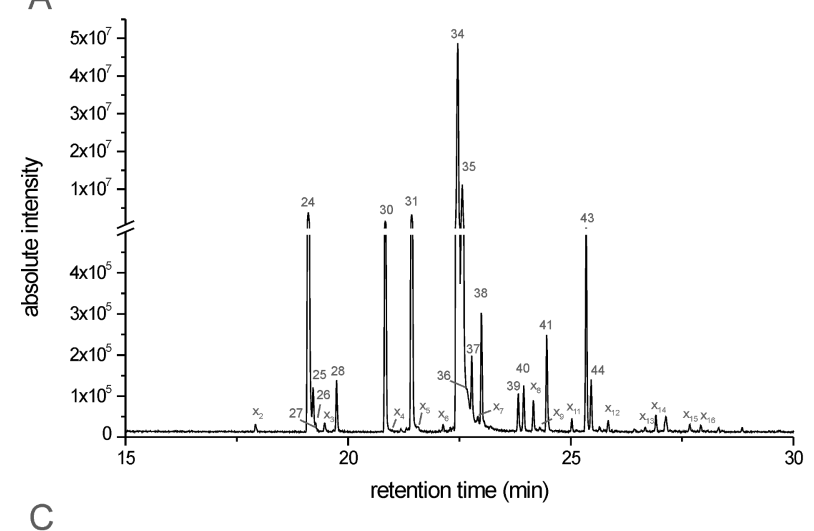

C

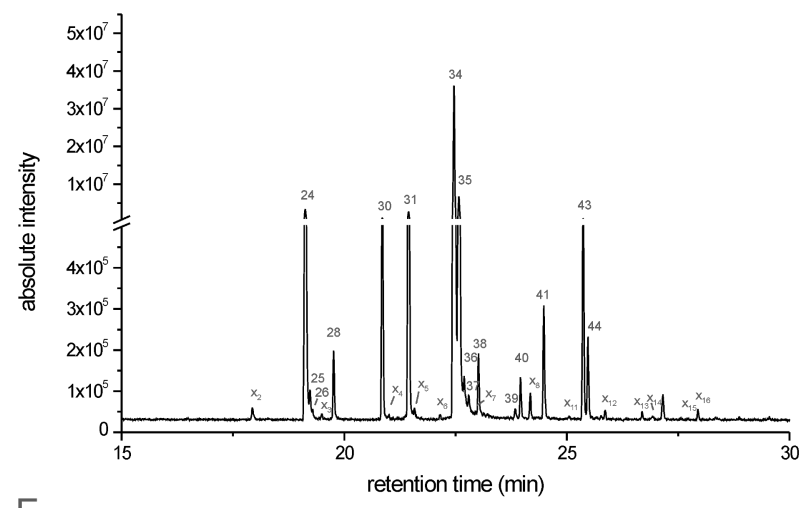

E

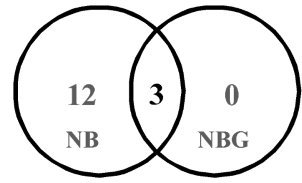

day 3

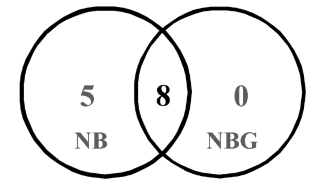

day 6

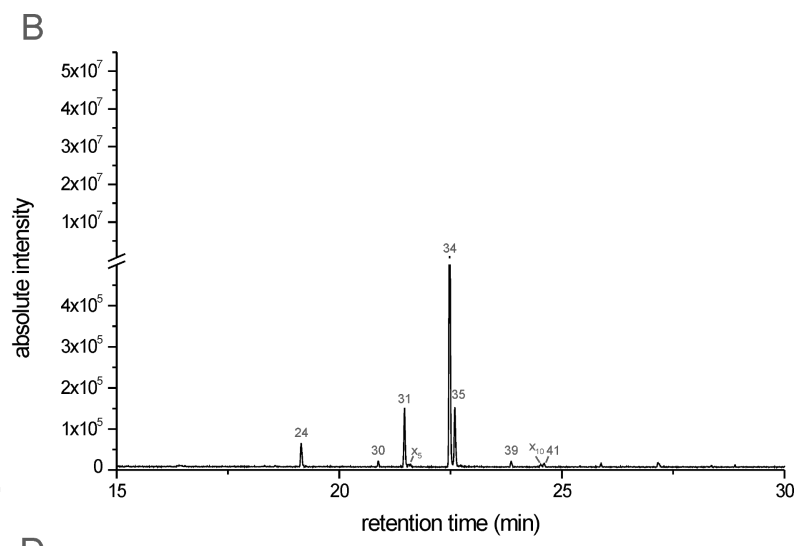

D

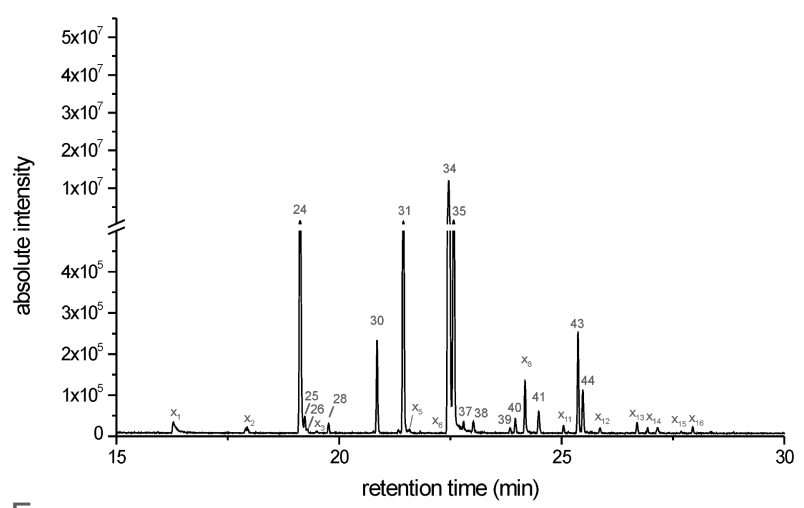

F

\begin{tabular}{|c|c|cc|cc|}
\hline \multirow{2}{*}{ peak } & \multirow{2}{*}{ compound } & \multicolumn{2}{|c|}{ NB (\%) } & \multicolumn{2}{|c|}{ NBG (\%) } \\
\cline { 3 - 6 } & & day 3 & day 6 & day 3 & day 6 \\
\hline 24 & 8-Methylnonan-2-one & 5 & 6 & 5.5 & 7.5 \\
30 & 9-Methyldecan-2-one & 2 & 2 & 1 & 1.5 \\
31 & Undecan-2-one & 4 & 5 & 11 & 6.5 \\
34 & 10-Methylundecan-2-one & 73 & 70 & 67.5 & 70 \\
35 & 9-Methylundecan-2-one & 13 & 13 & 12 & 9.5 \\
43 & 11-Methyltridecan-2-one & 1 & 1 & 1 & 1.5 \\
\hline
\end{tabular}

Figure 5: GC/MS analysis of volatiles emitted by Xanthomonas campestris pv. vesicatoria 85-10 grown on different media. (A) GC/MS-profile of headspace volatiles of $X$. c. pv. vesicatoria 85-10 grown on NB at day 3. (B) GC/MS-profile of headspace volatiles of $X$. c. pv. vesicatoria 85-10 grown on NBG at day 3. (C) GC/MS-profile of headspace volatiles of $X$. c. pv. vesicatoria 85-10 grown on NB at day 6 . (D) GC/MS-profile of headspace volatiles of $X$. c. pv. vesicatoria 85-10 grown on NBG at day 6. (E) Registration of volatiles reaching a threshold level $>1 \times 10^{5}$ when $X$. c. pv. vesicatoria 85-10 grew on NB (left circle) and NBG (right circle) (day 3: left panel, day 6: right panel). (F) Relative contribution (\%) of the six major volatiles emitted by Xanthomonas campestris pv. vesicatoria 85-10 at day 3 and 6 grown on NB and NBG.

Table 2: GC/MS analysis of SPME trapped volatiles emitted from Xanthomonas campestris pv. vesicatoria 85-10 grown in a Petri dish on NB or NBG. ${ }^{a}$

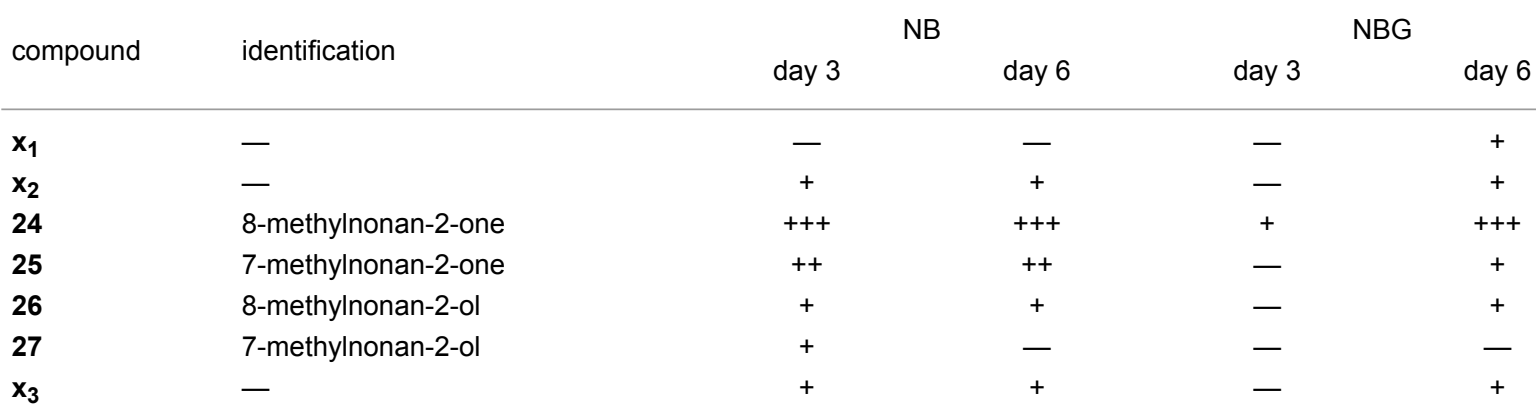




\begin{tabular}{|c|c|c|c|c|c|}
\hline 28 & decan-2-one & ++ & ++ & - & + \\
\hline 30 & 9-methyldecan-2-one & +++ & +++ & + & ++ \\
\hline $\mathbf{x}_{4}$ & - & + & + & - & - \\
\hline 31 & undecan-2-one & +++ & +++ & ++ & +++ \\
\hline$x_{5}$ & - & + & + & + & + \\
\hline$x_{6}$ & - & + & + & - & + \\
\hline 34 & 10-methylundecan-2-one & ++++ & ++++ & + & ++++ \\
\hline 35 & 9-methylundecan-2-one & ++++ & ++++ & ++ & +++ \\
\hline 36 & 10-methylundecan-2-ol & ++ & +++ & - & - \\
\hline 37 & 9-methylundecan-2-ol & ++ & + & - & + \\
\hline$x_{7}$ & - & + & + & - & - \\
\hline 38 & dodecan-2-one & ++ & ++ & - & + \\
\hline 39 & geranylacetone & ++ & + & + & + \\
\hline 40 & 11-methyldodecan-2-one & ++ & ++ & - & + \\
\hline$x_{8}$ & - & ++ & + & - & ++ \\
\hline$x_{9}$ & - & + & - & - & - \\
\hline $\mathbf{x}_{10}$ & - & - & - & + & - \\
\hline 41 & tridecan-2-one & ++ & ++ & + & + \\
\hline$x_{11}$ & - & + & + & - & + \\
\hline 43 & 12-methyltridecan-2-one & ++ & ++ & - & ++ \\
\hline 44 & 11-methyltridecan-2-one & ++ & ++ & - & ++ \\
\hline$x_{12}$ & - & + & + & - & + \\
\hline$x_{13}$ & - & + & + & - & + \\
\hline$x_{14}$ & - & + & + & - & + \\
\hline$x_{15}$ & - & + & + & - & + \\
\hline$x_{16}$ & - & + & + & - & + \\
\hline
\end{tabular}

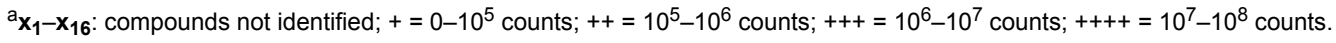

We also determined the contribution (\%) of each of the six major volatiles during bacterial growth (Figure $5 \mathrm{~F}$ ). The dominant compound, 10-methylundecan-2-one (34) comprised about $70 \%$ under the four growth conditions, followed by $10-12 \%$ of 9-methylundecan-2-one (35), about 5-7\% of 8-methylnonan-2one (24), 4-6\% undecan-2-one (31), and 1-2\% 9-methyldecan2-one (30) and 11-methyltridecan-2-one (44). All other compounds contributed less than $1 \%$ to the bouquets. It is interesting to note, that the ratios of the six major compounds did not significantly vary (except for undecan-2-one (31) at day 3 on NBG), indicating that the same metabolic pathways were active and only larger quantities/fluxes of the volatiles were emitted under the four different growth conditions.

Similarly, as performed with the GC/MS analysis, PTR-MS volatile profiles where obtained when $X . c$. pv. vesicatoria was grown on NB and NBG at day 3 and 6 . The PTR-MS pattern of $X$. c. pv. vesicatoria grown on NB for three (Figure 4A) and six days were quite similar (data not shown). It is remarkable that, in comparison, the signals for the later-eluting alkanones, i.e., $m / z 157,171$ and 185 especially, were absent or significantly lower when bacteria grew on NBG for three days (Figure 4B). Furthermore, $m / z=30,36,43,44,59,60,67$ and 109 appeared at higher levels in NB compared to NBG. Conversely, when bacteria were grown on NBG, the signals at $m / z=39,41,57$, 71,79 as well as 89 and 91 were enhanced. When the incubation time on NBG was prolonged to six days, even the alkanones contributed significantly, but still in about five-fold lower amounts.

\section{Individual volatiles of Xanthomonas campestris pv.} vesicatoria 85-10 marginally influence fungal growth As demonstrated in Figure 1, X. c. pv. vesicatoria 85-10 strongly inhibited the growth of Rhizoctonia solani and Aspergillus nidulans and to a certain extent that of Fusarium solani. The inhibition was stronger when $X$. c. pv. vesicatoria 85-10 was grown on NB as compared to NBG. Both methods, GC/MS and PTR-MS, indicated the emission of a multitude of volatile compounds, including many ketones. Decan-2-one (28), undecan-2-one (31), dodecan-2-one (38) and 10-methylundecan-2-one (34) were identified as major products of $X . c$. pv. vesicatoria 85-10. Since the ketones were released in 
different quantities from both media, we tested these ketones individually in different amounts or in combination, to find out whether the identified ketones influence the fungal growth (Figure 6). They were applied repetitively every $24 \mathrm{~h}$ at concentrations of $0.01,0.1,1.0,10$ and $100 \mu \mathrm{mol}$ in $50 \mu \mathrm{L}$ pentane (10-methylundecan-2-one (34) was applied at 0.01, 0.1 and $1 \mu \mathrm{mol}$ in $50 \mu \mathrm{L}$ pentane). The area of the fungal mycelium was determined after four days of cocultivation. Only at a concentration of $100 \mu \mathrm{mol}$ decan-2-one (28) the growth of $R$. solani was inhibited, by $30 \%$ (Figure 6), while the other ketones did not significantly influence the development of $R$. solani at any of the tested concentrations. Surprisingly, undecan-2-one (31) promoted the growth of $R$. solani by $10-15 \%$ at concentrations from 0.01 to $10 \mu \mathrm{mol}$ in $50 \mu \mathrm{L}$ and dodecan-2-one (38) at 0.01 and $0.1 \mu \mathrm{mol}$ in $50 \mu \mathrm{L}$. 10-Methylundecan-2-one (34) had no effect on the growth of $R$. solani. An additional bioassay, performed with a mixture of the four synthetic compounds (decan-2-one (28), undecan-2-one (31), dodecan-2-one (38), 10-methylundecan-2-one (34)) in the ratios that were emitted by the bacteria growing in the Petri dish (6.7\%:5.5\%:87.2\%:0.6\%), revealed $10 \%$ inhibition at $9 \mu \mathrm{mol}$ in $50 \mu \mathrm{L}$ and slight promotion (ca. $6 \%$ ) at $0.09 \mu \mathrm{mol}$ in $50 \mu \mathrm{L}$. These results indicate that the individual ketones neither acted additively nor synergisti- cally, and they were most likely not significantly responsible for inhibitory effects on the growth (Figure 1) of the fungi by $X . c$. pv. vesicatoria volatiles. We concluded that either the experimental design of the bioassay was not appropriate or other volatiles account for the inhibitory effects. In the literature, contradictory results were found for undecan-2-one (31). It is likely to be involved in the inhibition of sapstain fungi [40], while Sclerotinia sclerotiorum was not affected by 31 [22]. It must also be considered that it is not known whether the emitted volatile blends change qualitatively and quantitatively during the growth of $X$. c. pv. vesicatoria 85-10 [34]. Hence, to find the inhibitory component(s) and the bioactive concentrations, the emitted blends of volatiles must be investigated more comprehensively.

In addition, inorganic compounds have to be considered, including hydrogen cyanide (HCN) and ammonia. HCN is produced, e.g., by Pseudomonas spp. [55] and, due to its slightly higher proton affinity than water, it should be detectable down to a concentration lower than $100 \mathrm{ppb}$ by PTR-MS [56,57]. Nevertheless in our experiments with $X$. c. pv. vesicatoria $85-10$ we did not detect any significant signal at $m / z=28$ corresponding to $\mathrm{HCN}$. Ammonia emissions by $X$. vesicatoria
A

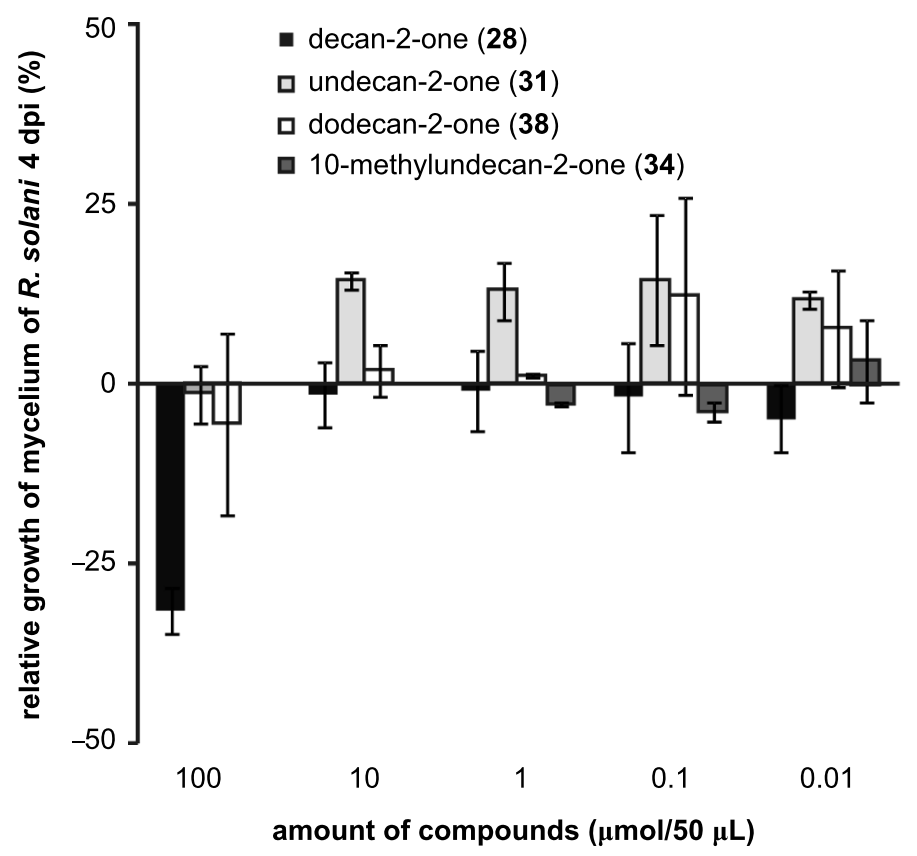

B

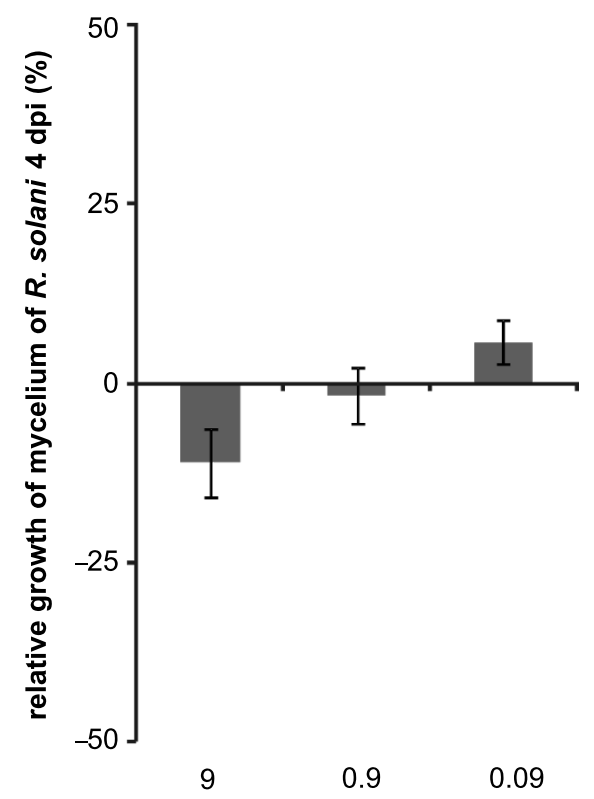

amount of compound mixture ( $\mu \mathrm{mol} / 50 \mu \mathrm{L})$

Figure 6: Testing synthetic volatiles on the growth of Rhizoctonia solani. Synthetic commercially available and chemically synthesized ketones were dissolved in pentane and applied on a filter-paper disc in aliquots of $50 \mu \mathrm{L}$. The filter paper was placed in the opposite compartment to the $R$. solani in a bi-partite Petri dish. Defined dilutions or mixtures were applied every $24 \mathrm{~h}$. At day 4 the diameter of the mycelium was measured and compared to control plates containing pentane. Positive values represent growth promotion and negative values growth inhibition of $R$. solani compared to the control. Data are from two experiments each replicated three times; the standard deviation is presented. (A) Decan-2-one (28) (black), undecan-2-one (31) (light grey), dodecan-2-one (38) (white), and 10-methylundecan-2-one (34) (dark grey) were individually applied in $50 \mu \mathrm{L}$ aliquots each day (day 0 to day 4). (B) A mixture of $28, \mathbf{3 1}, 38$ and 34 (6.7\%:5.5\%:0.6\%:87.2\%) was applied in $50 \mu \mathrm{L}$ aliquots every day (day 0 to day 4 ). 
and of two Bacillus subtilis strains in cocultivation with Neurospora crassa were described [58,59]. Ammonia is of course an important nitrogen source for organisms, but recently other roles were also attributed to ammonia. Nijland and Burgess [60] suggested that ammonia acts as an olfactory cue in the communication of Bacillus licheniformis strains, and Bernier et al. [61] showed that elevated ammonia levels lead to increased polyamine levels in E. coli with consequences for the membrane permeability and increased antibiotic resistance. Other volatiles such as $\mathrm{CO}, \mathrm{CH}_{4}, \mathrm{CH}_{2} \mathrm{O}$ and $\mathrm{NO}$ were not detectable with the applied methods. However, the PTR provides evidence for the emission of sulfur-containing compounds such as $\mathrm{H}_{2} \mathrm{~S}(\mathrm{~m} / \mathrm{z}=35)$ and methanethiol $(\mathrm{m} / \mathrm{z}=49)$, as has been suggested for other microorganisms [52]. The compound producing $m / z=33$ was tentatively assigned to be methanol in accordance with published data [52]. Methanol is so far not known as a prominent compound released by bacteria. In addition to the Enterobacteriaceae E.coli, Shigella flexneri, and Salmonella enterica also $X$. vesicatoria may emit methanol. The release of $\mathrm{CO}_{2}$ due to the active tricarboxylic acid cycle is very likely, but $\mathrm{CO}_{2}$ does not accumulate at higher than ambient concentrations in the open experimental system [62] and, therefore, cannot be considered as a growth-promoting or -inhibitory component.

\section{Considerations concerning methodological approaches}

It is quite obvious that further research is necessary to identify the bioactive compounds, especially those sensitive and/or highly volatile substances that escaped conventional GC/MSanalysis. During our investigations on volatiles of Xanthomonas we noticed a discrepancy in the number of compounds detected in the headspace of a $10 \mathrm{~L}$ liquid-medium culture versus growth on solid medium (Petri dish). Beside the known physiological adaptations of bacteria growing on liquid and solid media, the different trapping material (Super-Q versus polydimethylsiloxane) and the experimental procedure (30 hour trapping versus 2 hour trapping) most likely account for those differences. As discussed above, the suitability of PTR-MS for compound identification is limited. Therefore, structure assignments are based on comparison with GC/MS data (i.e., as performed also in this work) and literature-based information. Selectivity may be enhanced by using ammonia as the primary ion-source gas. Ammonia has a higher proton affinity than water, and therefore, some substance classes can be ionized selectively (e.g., nitrogen-containing compounds). Further information to discriminate nominally isobaric compounds could be obtained by using proton-transfer-reaction ion-trap mass spectrometry (PIT-MS), which allows tandem mass spectrometric experiments (MS/MS) [63,64], or by high-resolution PTR-TOF-MS for the determination of exact molecular masses and assignment of atomic compositions. Regarding quantitative analysis, some striking differences between results obtained with extracts or solid-phase micro extraction (SPME) applying conventional GC/MS and PTR-MS, respectively, have been observed. As an example, in PTR-MS analyses the signal at $\mathrm{m} / \mathrm{z}=109$ is about as intensive as those produced by the methyl ketones at $m / z=157, m / z=171$, and $m / z=185$ (Figure 4A). In contrast, in our GC/MS analyses the sum of 2,5-dimethylpyrazine (8) and benzylalcohol (18) (Figure 2, Table 1), which may give rise to $m / z=109$ (provided that there is no abundant compound that did not survive GC), never exceeded $5 \%$ of 10-methylundecan-2-one (34). These discrepancies require further investigations. The most important future analytical aspect will be online PTR-MS, tracing the dynamics in the emission of volatiles during incubation time, considering both qualitative and quantitative compositions of the profiles. In addition, gas-chromatographic analyses of highly volatile compounds, by using either direct headspace injection or solidphase adsorption/thermodesorption separation on thick film capillaries connected to a GC/MS system, will have to be carried out.

\section{Conclusion}

Profiles of volatiles emitted by Xanthomonas $c$. pv. vesicatoria 85-10 were investigated by using GC/MS and PTR-MS techniques. More than 50 compounds were emitted by this species, the majority comprising ketones and methylketones, including 10-methylundecan-2-one (34) as the largely dominant component. The emission profiles differed depending on whether the bacteria were grown on a medium with or without glucose. To better understand the involvement of $X$. c. pv. vesicatoria volatiles in antagonistic processes against fungi, more ecological information is required. Most obviously it needs to be addressed as to whether $X$. c. pv. vesicatoria 85-10 emits volatiles while growing in the phyllosphere and whether the emission occurs continuously. Continuous volatile perception by the plant may be a prerequisite to induce signal cascades in the plant, similarly to the behavior shown for repetitive wounding in contrast to single cuts in plants [65]. Furthermore, a possible role of volatiles in achieving a better colonization of the aerial parts by $X . c$. pv. vesicatoria has to be considered. Another question of concern is whether and how the plants are directly affected by the volatiles of $X$. c. pv. vesicatoria 85-10. Plant growth promotion as well as inhibition is reflected at the molecular and physiological level of Arabidopsis thaliana and of Physcomitrella patens [23,27,31,34,62,66]. However, in most of these studies the bioactive compound(s) need to be determined. Therefore, future tasks must focus on (i) the comprehensive determination of volatile profiles of bacteria of the phyllosphere as well as in the rhizosphere and (ii) the identification of biologically active volatiles. 


\section{Experimental}

\section{Bacterial cultures}

Xanthomonas campestris pv. vesicatoria 85-10 was originally isolated from Capsicum sp. The bacterial strain was kindly provided by Prof. U. Bonas (University of Halle/Wittenberg). It was stored in frozen stocks at $-70{ }^{\circ} \mathrm{C}$ and grown on nutrient broth (NB) II agar (SIFIN, Berlin) either with or without $1.1 \%$ glucose (Merck, Darmstadt) at $30^{\circ} \mathrm{C}$.

\section{Fungal isolates}

Aspergillus nidulans (FGCS A4) was kindly provided by Dr. S. Busch (University of Göttingen). Fusarium solani and Rhizoctonia solani KÜHN (RHI S0 WE) were obtained from the Strain Collection of Antagonistic Microorganisms (SCAM; University of Rostock, Microbiology). Fungal mycelium was grown on Sabouraud agar (Dinkelberg Analytics $\mathrm{GmbH}$, Regensburg) with a mycelia plug from stock cultures stored at $-70{ }^{\circ} \mathrm{C}$. To maintain the fungi, every seventh day a mycelium disk was transferred from the edge of an actively growing fungus to a new agar plate. Cultures were incubated at $20^{\circ} \mathrm{C}$ in the dark.

\section{Cocultivation of Xanthomonas campestris pv. vesicatoria 85-10 with fungi}

Bacteria were grown on nutrient agar (NB II; peptone from casein $3.5 \mathrm{~g} \cdot \mathrm{L}^{-1}$, peptone from meat $2.5 \mathrm{~g} \cdot \mathrm{L}^{-1}$, peptone from gelatin $2.5 \mathrm{~g} \cdot \mathrm{L}^{-1}$, yeast extract $1.5 \mathrm{~g} \cdot \mathrm{L}^{-1}, \mathrm{NaCl} 5 \mathrm{~g} \cdot \mathrm{L}^{-1}$, agaragar $15 \mathrm{~g} \cdot \mathrm{L}^{-1}, \mathrm{pH} 7.2$ ), and nutrient agar with glucose (NBG; NB plus $11 \mathrm{~g} \cdot \mathrm{L}^{-1}$ glucose) at $30^{\circ} \mathrm{C}$. Cocultivations of bacteria and fungi were performed in bi-partite Petri dishes. One milliliter of the overnight cultures of Xanthomonas grown on NB or NBG was transferred into $100 \mathrm{~mL}$ fresh medium in $250 \mathrm{~mL}$ chicane flasks and incubated by shaking overnight at $30{ }^{\circ} \mathrm{C}$. Fifty microliters of these cultures were plated onto nutrient agar, with or without glucose, in one compartment of the Petri dish and cultivated at $30^{\circ} \mathrm{C}$. Three days later (day 0 of cocultivation) a seven-day-old $6 \mathrm{~mm}$ disk of actively grown mycelium of the tested fungus was transferred to Sabouraud agar in the other compartment of the Petri dish. Cocultivation was performed at $20^{\circ} \mathrm{C}$ in the dark. Digital images were taken after four days. Growth of fungi was determined by measuring the diameter of the mycelium and compared to the control (without adjacent bacterial growth). Average values were calculated based on three experiments each with three to five replicates.

\section{Analysis of volatiles produced by Xanthomonas campestris pv. vesicatoria 85-10}

Cultivation in liquid medium: A single colony of $X$. c. pv. vesicatoria was picked and suspended in $6 \mathrm{~mL}$ of $\mathrm{NB}$ medium. After incubation for $24 \mathrm{~h}$ at $30^{\circ} \mathrm{C}$ and shaking at $180 \mathrm{rpm}$,
$1 \mathrm{~mL}\left(\mathrm{OD}_{600}=0.8-1.4\right)$ was used as inoculum for a $250 \mathrm{~mL}$ NB culture. The preculture $(100 \mathrm{~mL})$ was used to inoculate $10 \mathrm{~L}$ of the culture medium in a 20 L Duran ${ }^{\circledR}$ wide-necked glass flask closed with a specially designed glass cap (equipped with an inlet and an outlet). During growth, the bacterial culture was stirred with a magnetic stir bar at $600 \mathrm{rpm}$ and incubated at $30{ }^{\circ} \mathrm{C}$. A diaphragm pump (Denver Gardner, Puchheim, Germany) pulled charcoal-purified, sterile air at a flow of $3 \mathrm{~L} / \mathrm{min}$ through the system. Volatiles released during a 30 hours growth of $X$. c. pv. vesicatoria were trapped on SuperQ (100 mg, Alltech Associates, Deerfield, IL, USA). The collected volatiles were eluted three times with $500 \mu \mathrm{L}$ dichloromethane and further analysed. Gas chromatography coupled with mass spectrometry (GC/MS) was carried out by linking a gas chromatograph HP 5890 (Hewlett Packard, Palo Alto, US) to a double-focusing spectrometer (VG-7070/250SE, Vacuum Generators, Manchester, UK). By using helium as the carrier gas, separations were achieved with a $50 \mathrm{~m} \times 0.25 \mathrm{~mm}$ id CPSil5 fused silica column (Chrompack, Middleburg, The Netherlands) under the following conditions: injector temperature $250{ }^{\circ} \mathrm{C}, 1 \mathrm{~min}$ splitless, $1 \mathrm{~min}$ at $50^{\circ} \mathrm{C}$, then programmed to increase to $290{ }^{\circ} \mathrm{C}$ at a rate of $3.5^{\circ} \mathrm{C} / \mathrm{min}$. Identification of volatiles was based on comparison of their mass spectra with those reported in the literature $[67,68]$ as well as with the analytical data of commercially available or specifically synthesized reference compounds (co-injection). Synthetic 10-methylundecan-2-one and 9-methylundecan-2-one served as standards for the structure assignments of other branched-chain methyl ketones on the basis of their mass spectra and retention indices.

Cultivation on solid medium: In another analytical approach, solid-phase micro extraction (SPME) was applied to trap volatiles, which were subsequently analyzed by GC/MS. Bi-partite glass Petri dishes with a borehole (1 mm diameter) at the side of one compartment were used for SPME. The preculture $(1 \mathrm{~mL})$ was used to inoculate $100 \mathrm{~mL} \mathrm{NB}$ or NBG medium in a $250 \mathrm{~mL}$ chicane flask. After $24 \mathrm{~h}$ of incubation at $30^{\circ} \mathrm{C}$, $50 \mu \mathrm{L}$ was plated on NB or NBG agar on one side of the compartmentalized Petri dish. Similarly to the cocultivation tests, the inoculated plate was incubated for three days at $30^{\circ} \mathrm{C}$ under darkness. The collection of volatiles was performed at day 3 and day 6 after inoculation at $20^{\circ} \mathrm{C}$ in the dark. A $100 \mu \mathrm{m}$ polydimethylsiloxane (PDMS; SUPELCO, Bellefonte, USA) coated SPME-fiber was preconditioned to remove all contaminants $\left(30 \mathrm{~min}, 250^{\circ} \mathrm{C}\right)$. Subsequently, the SPME needle was introduced into the Petri dish through the hole, and the fiber was extended into the headspace. The time for the adsorption and accumulation of bacterial volatiles was set to $2 \mathrm{~h}$. Volatile compounds were thermally desorbed and analyzed by using a GC/MS-QP5000 (Shimadzu; Kyoto, Japan, injection port set at $250{ }^{\circ} \mathrm{C}$ ). The initial temperature of the DB5-MS column 
$(60 \mathrm{~m} \times 0.25 \mathrm{~mm} \times 0.25 \mu \mathrm{m}$; J\&W Scientific, Folsom, California, USA) was kept at $35{ }^{\circ} \mathrm{C}$ for $5 \mathrm{~min}$, increased to $280{ }^{\circ} \mathrm{C}$ at a rate of $10{ }^{\circ} \mathrm{C} / \mathrm{min}$, and then kept constant for $15 \mathrm{~min}$. Helium at a flow rate of $1.1 \mathrm{~mL} / \mathrm{min}$ was used as the carrier gas with a linear velocity of $28 \mathrm{~cm} / \mathrm{s}$. Electron ionization (EI) mass spectra were taken at $70 \mathrm{eV}$. The mass range was $m / z=40-280$. Compounds were identified by using available reference compounds and the library of the National Institute of Standards and Technology (NIST147) for the comparison of mass spectra, retention times and Kovats indices [69]. Analysis of the volatile emissions was replicated twice, and compounds emitted by the NB or NBG agar (blank) were subtracted.

Highly volatile components produced by $X$. campestris pv. vesicatoria $85-10$ were monitored by proton transfer reaction mass spectrometry (PTR-MS). This technique allows continuous online monitoring of mixtures of volatiles at the parts-perbillion (ppb) level. The method is a special variant of the wellestablished chemical ionization mass spectrometry. In PTR-MS, the hydronium ion $\mathrm{H}_{3} \mathrm{O}^{+}$is the primary species to generate the protonated analyte $(\mathrm{M}+\mathrm{H})^{+}$, which is recorded by the detector. The PTR-MS (Ionicon, Innsbruck, Austria) used in this investigation has been described elsewhere [70]. As a modification to this original PTR-MS a heated inlet system was installed to prevent condensation and to enable also a qualitative analysis of less volatile compounds. It consists of a deactivated $2 \mathrm{~m}$ long GC capillary (ID $0.53 \mathrm{~mm}$, MXT Guard Column, BGB-Analytik, Schlossboeckelheim, Germany) integrated in a $1 / 8$ inch copper tube and maintained at a temperature of $60^{\circ} \mathrm{C}$ by using a heating hose (Horst GmbH, Lorsch, Germany). The sample flow through the capillary is $80 \mathrm{~mL} / \mathrm{min}$. Drift tube pressure was set to $2.0 \mathrm{mbar}$ and drift voltage to $600 \mathrm{~V}$. These settings resulted in very sensitive measurements, but some side reactions led to fragmentation of, e.g., aldehydes, as described for a SWIFT instrument by Blake et al. [54]. Massto-charge ratios from 20 to 250 unified mass units $(\mathrm{m} / \mathrm{z})$ were run by using a quadrupole at a dwell time of $100 \mathrm{~ms}$ per $\mathrm{m} / \mathrm{z}$ resulting in a repetition rate of about two full mass spectra per minute. Generally 100 spectra were recorded. For PTR-analysis the Petri dish with growing bacteria were placed at day 3 and 6 , without the lid, into a glass compartment (Petri dish, $145 \mathrm{x}$ $30 \mathrm{~mm}$ ) with an in- and outlet. Charcoal-purified air was passed over the culture and entered the PTR instrument through the inlet. All analyses of bacterial metabolites were carried out in triplicate. Blank samples of NB and NBG were analyzed twice to identify compounds directly related to outgasing of the nutrient agar. For data evaluation, raw spectra of each measurement (100 spectra) were first normalized to the signal of the primary ion $\left(\mathrm{H}_{3} \mathrm{O}^{+}\right)$, to enable a semiquantitative data evaluation and a direct comparison of spectra that were obtained at different days with a slightly different sensitivity. As a second step these normalized raw spectra were averaged and blankvalue corrected. Statistical analyses of bacterial metabolites on NB and NBG were performed by using a variant of the T-test, with a $5 \%$ confidence level [71].

\section{Syntheses of reference compounds}

The syntheses of 10-methylundecan-2-one (34) and 9-methylundecan-2-one (35) proceeded straightforwardly, following a conventional alkyne approach (Scheme 1). Commercially available (Aldrich) 4-pentyne-2-ol was reacted with benzyl chloride to yield the corresponding benzyl ether A. Subsequently, A was coupled to commercially available (Aldrich) 1-bromo-5-methylhexane (B) according to the standard procedure [72]. The resulting 2-benzyloxy-10-methylundec-4-yne (C) was hydrogenated over $10 \% \mathrm{Pd} / \mathrm{C}$-catalyst at $1 \mathrm{~atm}$. The crude secondary alcohol was oxidized with pyridinium dichromate $[73,74]$ to yield the corresponding ketone. Purification by column chromatography on silica (ICN, pore size $60 \AA$, particle size $32-63 \mu \mathrm{m}$ ) with cyclohexane/ethyl acetate 20:1 followed by Kugelrohr distillation at $20 \mathrm{mmHg}$ afforded 10-methylundecan-2-one (34) in a purity of $98 \%$. Analytical data of the product were identical to those reported in the literature [47]. Following the same route as for the synthesis of $\mathbf{3 4}$ (Scheme 1), 9-methylundecan-2-one (35), was prepared by coupling 1-bromo-4-methylhexane $\left(\mathbf{B}^{\prime}\right)$ [75] to A. Hydrogenation of the obtained $\mathbf{C}^{\prime}$ followed by oxidation of the obtained alcohol yielded $\mathbf{3 5}$.

Synthesis of 9-methylundecan-2-one (35): To a stirred, icecooled solution of $2.0 \mathrm{~g}(23.8 \mathrm{mmol}) \mathrm{rac}-4$-pentyne-2-ol in $50 \mathrm{~mL}$ dry THF was slowly added $1.20 \mathrm{~g}$ (49.9 mmol) sodium hydride. The reaction mixture was warmed to room temperature, and stirring was continued until the formation of hydrogen ceased. Subsequently, a solution of $4.27 \mathrm{~g}(25.0 \mathrm{mmol})$ benzyl bromide in $50 \mathrm{~mL}$ dry THF was added slowly. After $3 \mathrm{~h}$ stirring at $\mathrm{RT}, 150 \mathrm{~mL}$ water was added, and the mixture was extracted with three portions of diethyl ether at $50 \mathrm{~mL}$ each. The combined organic solutions were washed with a saturated aqueous solution of sodium hydrogen carbonate and brine and dried over magnesium sulfate. The solvent was removed in vacuo, and the residue was submitted to flash chromatography (silica; cyclohexane/ethyl acetate 40:1) yielding $2.44 \mathrm{~g}$ (29.8 mmol, 83\%) of 2-benzyloxypent-3-yne (A).

A solution of $2.70 \mathrm{~g}(15.5 \mathrm{mmol})$ of $\mathbf{A}$ in $50 \mathrm{~mL}$ dry THF was cooled to $-78{ }^{\circ} \mathrm{C}$ and deprotonated with $10.6 \mathrm{~mL}$ of a $1.6 \mathrm{M}$ solution of butyl lithium in hexane, which was added slowly. After warming to RT, $3.05 \mathrm{~g}$ (17.0 mmol) of 1-bromo-4-methylhexane (B'), dissolved in $15 \mathrm{~mL}$ dry THF, was added dropwise. After heating under reflux for $12 \mathrm{~h}$, the mixture was cooled to $\mathrm{RT}$, and $150 \mathrm{~mL}$ of a saturated aqueous solution of ammonium chloride was added. After separation, the aqueous layer was 
extracted with three portions of diethyl ether at $50 \mathrm{~mL}$ each. The combined organic solutions were washed with brine and dried over magnesium sulfate. The solvent was removed in vacuo, and the residue was submitted to flash chromatography (silica; cyclohexane/ethyl acetate $40: 1$ ) to yield $2.7 \mathrm{~g}$ (10.0 mmol, 64\%) of 2-benzyloxy-9-methylundec-4-yne $\left(\mathbf{C}^{\prime}\right)$. A solution of $2.53 \mathrm{~g}(9.3 \mathrm{mmol})$ of crude $\mathbf{C}^{\prime}$ in $50 \mathrm{~mL}$ methanol was hydrogenated overnight at 20 bar by using $20 \%$ PD/C-catalyst. The mixture was filtered over silica, and the solvent was removed in vacuo.

To a solution of $950 \mathrm{mg}(5.1 \mathrm{mmol})$ of the crude 9-methylundecane-2-ol in $50 \mathrm{~mL}$ dichloromethane was added $2.3 \mathrm{~g}$ (1.2 equiv) pyridinium dichromate, and the mixture was vigorously stirred for $12 \mathrm{~h}$ at RT. As a gas-chromatographic control revealed the reaction to be incomplete, another 1.2 equiv of pyridinium dichromate was added, and the mixture was heated under reflux for $6 \mathrm{~h}$. After filtration over silica and concentration in vacuo, the crude ketone was purified by column chromatography on silica with cyclohexane/diethyl ether 20:1. A final Kugelrohr distillation of $20 \mathrm{mmHg}$ afforded $855 \mathrm{mg}$ (4.6 mmol) of 9-methylundecan-2-one (35). The total yield over four steps was about $45 \%$, the obtained product showing a purity of ca. 98\%. ${ }^{1} \mathrm{H}$ NMR $\left(500 \mathrm{MHz}, \mathrm{CDCl}_{3}\right) \delta 0.83(\mathrm{~d}, J=6.1 \mathrm{~Hz}, 3 \mathrm{H}$, $\left.\mathrm{CH}_{3} \mathrm{C} 12\right), 0.85$ (t, $\left.J=7.2 \mathrm{~Hz}, 3 \mathrm{H}, \mathrm{CH}_{3} \mathrm{C} 11\right), 1.03-1.10 /$ 1.22-1.30 (2m, 2H, $\left.\mathrm{CH}_{2} \mathrm{C} 8\right), 1.06-1.17 / 1.20-1.30(2 \mathrm{~m}, 2 \mathrm{H}$, $\left.\mathrm{CH}_{2} \mathrm{C} 10\right), 1.21-1.32\left(\mathrm{~m}, 6 \mathrm{H}, 3 \times \mathrm{CH}_{2} \mathrm{C} 5-\mathrm{C} 7\right), 1.24-1.33$ (m, $1 \mathrm{H}, \mathrm{CH} \mathrm{C} 9), 1.52-1.61$ (m, 2H, $\left.\mathrm{CH}_{2} \mathrm{C} 4\right), 2.13$ (s, 3H, $\mathrm{CH}_{3} \mathrm{C} 1$ ), $2.41\left(\mathrm{t}, J=7.5 \mathrm{~Hz}, 2 \mathrm{H}, \mathrm{CH}_{2} \mathrm{C} 3\right) \mathrm{ppm} ;{ }^{13} \mathrm{C} \mathrm{NMR}(101 \mathrm{MHz}$, $\mathrm{C}_{6} \mathrm{D}_{6}$ ) $\delta 11.54$ (q, C11), 19.35 (q, C12), 24.04 (t, C4), 27.06 (t, C7), 29.38 (t, C5), 29.62 (t, C10), 29.90 (t, C6), 29.99 (q, C1), 34.52 (d, C9), 36.70 (t, C8), 43.99 (t, C3), 209.16 (s, C2) ppm; GC/MS (EI, $70 \mathrm{eV}$ ) $m / z$ (\% relative intensity): 39 (8), 41 (35), 42 (6), 43 (100), 56 (7), 57 (23), 58 (94), 59 (37), 67 (4), 68 (3), 69 (9), 70 (11), 71 (49), 81 (6), 82 (8), 83 (6), 85 (11), 95 (9), 96 (14), 97 (8), 109 (5), 110 (3), 124 (4), 126 (4), 127 (4), 137 (4), 166 (2), 169 (1), 184 (4); Anal. calcd for $\mathrm{C}_{12} \mathrm{H}_{24} \mathrm{O}: \mathrm{C}$, 78.20; H, 13.12; found: C, 77.52; H, 13.16 .

\section{Influence of individual volatiles of Xanthomonas campestris pv. vesicatoria 85-10 on the growth of different fungi}

Synthetic ketones identified as volatiles of Xanthomonas (decan-2-one (28), undecan-2-one (31), 10-methylundecan-2one (34), dodecan-2-one (38)) were assayed in bi-partite Petri dishes with $R$. solani as the test organism. A seven-day-old $6 \mathrm{~mm}$ disk of actively grown mycelium was transferred to Sabouraud agar, to one compartment of the Petri dish. Pentane solutions of synthetic compounds were prepared in different concentrations in decade steps $(0.01-100 \mu \mathrm{mol}$ in $50 \mu \mathrm{L})$. In addition, a blend of the four synthetic compounds in defined ratios
(28:31:34:38 6.7\%:5.5\%:87.2\%:0.6\%) was tested as well. Fifty microliters of each mixture $(0.09-9 \mu \mathrm{mol})$ were applied on filter paper $\left(1 \mathrm{~cm}^{2}\right)$, which was deposited at the other compartment of the Petri dish. Control experiments were performed with pentane alone. Similarly to the cocultivation test, the bioassay with individual compounds was performed at $20^{\circ} \mathrm{C}$ in the dark. Every $24 \mathrm{~h}$ the filter paper was replaced by a freshly prepared filter paper with $50 \mu \mathrm{L}$ of the respective test solution. Growth inhibition of fungi was determined by measuring the diameter of the mycelium at day 4 of the experiment and by comparison to the control experiment (pure pentane). Average values were calculated based on two repeat experiments each with three replicates.

\section{Acknowledgements}

The authors thank the DFG for financial support (Pi153/26 resp. FR507/19-1). We are grateful to Dr. Ulla Bonas for providing Xcv 85-10 and Dr. S. Busch for Aspergillus nidulans (FGCS A4). We like to thank Claudia Dinse for technical assistance.

\section{References}

1. Ruinen, J. Plant Soil 1961, 15, 81-109. doi:10.1007/BF01347221

2. Last, F. T.; Deighton, F. C. Trans. Br. Mycol. Soc. 1965, 48, 83-99. doi:10.1016/S0007-1536(65)80011-0

3. Blakeman, J. P.; Fokkema, N. J. Annu. Rev. Phytopathol. 1982, 20 , 167-190. doi:10.1146/annurev.py.20.090182.001123

4. Preece, T. F.; Dickinson, C. H., Eds. Ecology of leaf surface microorganisms; Academic Press: London, 1971.

5. Hirano, S. S.; Upper, C. D. Microbiol. Mol. Biol. Rev. 2000, 64, 624-653. doi:10.1128/MMBR.64.3.624-653.2000

6. Yang, C. H.; Crowley, D. E.; Borneman, J.; Keen, N. T. Proc. Natl. Acad. Sci. U. S. A. 2001, 98, 3889-3894. doi:10.1073/pnas.051633898

7. Lindow, S. E.; Leveau, J. H. J. Curr. Opin. Biotechnol. 2002, 13, 238-243. doi:10.1016/S0958-1669(02)00313-0

8. Lindow, S. E.; Brandl, M. T. Appl. Environ. Microbiol. 2003, 69, 1875-1883. doi:10.1128/AEM.69.4.1875-1883.2003

9. Doidge, E. M. J. Dep. Agric., Union S. Afr. 1921, 1, 718-721.

10. Hayward, A. C. The hosts of Xanthomonas. In Xanthomonas; Swings, J. G.; Civerolo, E. L., Eds.; Chapmann \& Hall: London, 1993; pp 1-119.

11. Gürlebeck, D.; Thieme, F.; Bonas, U. J. Plant Physiol. 2006, 163, 233-255. doi:10.1016/j.jplph.2005.11.011

12. Opelt, K.; Berg, G. Appl. Environ. Microbiol. 2004, 70, 6569-6579. doi:10.1128/AEM.70.11.6569-6579.2004

13. Wang, L.; He, Y.; Gao, Y.; Wu, J. E.; Dong, Y.; He, C.; Wang, S. X.; Weng, L.; Xu, J.; Tay, L.; Fang, R. X.; Zhang, L. Mol. Microbiol. 2004, 51, 903-912. doi:10.1046/j.1365-2958.2003.03883.x

14. Hogan, D. A.; Vik, A.; Kolter, R. Mol. Microbiol. 2004, 54, 1212-1223. doi:10.1111/j.1365-2958.2004.04349.x

15. Rasmann, S.; Köllner, T. G.; Degenhardt, J.; Hiltpold, I.; Toepfer, S.; Kuhlmann, U.; Gershenzon, J.; Turlings, T. C. J. Nature 2005, 434, 732-737. doi:10.1038/nature03451 
16. Hamilton-Kemp, T. R.; McCracken, C. T., Jr.; Loughrin, J. H.; Andersen, R. A.; Hildebrand, D. F. J. Chem. Ecol. 1992, 18, 1083-1091. doi:10.1007/BF00980064

17. Pandey, V. N.; Dubey, N. K. Biol. Plant. 1992, 34, 143-147. doi:10.1007/BF02925809

18. Trombetta, D.; Castelli, F.; Sarpietro, M. G.; Venuti, V.; Cristani, M.; Daniele, C.; Saija, A.; Mazzanti, G.; Bisignano, G. Antimicrob. Agents Chemother. 2005, 49, 2474-2478. doi:10.1128/AAC.49.6.2474-2478.2005

19. Wink, M. Importance of plant secondary metabolites for protection against insects and microbial infections. In Naturally occurring bioactive compounds; Carpinella, M. C.; Rai, M., Eds.; Advances in Phytomedicine, Vol. 3; Elsevier: Amsterdam, 2006; pp 251-268.

20. Kai, M.; Haustein, M.; Molina, F.; Petri, A.; Scholz, B.; Piechulla, B. Appl. Microbiol. Biotechnol. 2009, 81, 1001-1012. doi:10.1007/s00253-008-1760-3

21. Wenke, K.; Kai, M.; Piechulla, B. Planta 2010, 231, 499-506. doi:10.1007/s00425-009-1076-2

22. Fernando, W. G. D.; Ramarathnam, R.; Krishnamoorthy, A. S.; Savchuk, S. C. Soil Biol. Biochem. 2005, 37, 955-964. doi:10.1016/j.soilbio.2004.10.021

23. Kai, M.; Effmert, U.; Berg, G.; Piechulla, B. Arch. Microbiol. 2007, 187, 351-360. doi:10.1007/s00203-006-0199-0

24. Schulz, S.; Dickschat, J. S. Nat. Prod. Rep. 2007, 24, 814-842. doi:10.1039/b507392h

25. Kai, M.; Piechulla, B. Plant Signal. Behav. 2010, 5, 444-446. doi:10.4161/psb.5.4.11340

26. Fiddaman, P. J.; Rossall, S. J. Appl. Microbiol. 1993, 74, 119-126. doi:10.1111/j.1365-2672.1993.tb03004.x

27. Vespermann, A.; Kai, M.; Piechulla, B. Appl. Environ. Microbiol. 2007, 73, 5639-5641. doi:10.1128/AEM.01078-07

28. Chun, W.; Cui, J.; Poplawsky, A. Physiol. Mol. Plant Pathol. 1997, 51, 1-14. doi:10.1006/pmpp.1997.0096

29. Fiddaman, P. J.; Rossall, S. J. Appl. Bacteriol. 1994, 76, 395-405. doi:10.1111/j.1365-2672.1994.tb01646.x

30. Strobel, G. A.; Dirkse, E.; Sears, J.; Markworth, C. Microbiology (Reading, U. K.) 2001, 147, 2943-2950.

31. Ryu, C. M.; Farag, M. A.; Hu, C. H.; Reddy, M. S.; Wie, H. X.; Pare, P. W.; Kloepper, J. W. Proc. Natl. Acad. Sci. U. S. A. 2003, 100, 4927-4932. doi:10.1073/pnas.0730845100

32. Zhang, H.; Kim, M. S.; Krishnamachari, V.; Payton, P.; Sun, Y.; Grimson, M.; Farag, M. A.; Ryu, C. M.; Allen, R.; Melo, I. S.; Pare, P. W. Planta 2007, 226, 839-851. doi:10.1007/s00425-007-0530-2

33. Zhang, H.; Xie, X.; Kim, M. S.; Kornyeyev, D. A.; Holaday, S.; Pare, P. W. Plant J. 2008, 56, 264-273. doi:10.1111/j.1365-313X.2008.03593.x

34. Kai, M.; Crespo, E.; Cristescu, S. M.; Harren, F. J. M.; Francke, W.; Piechulla, B. Appl. Microbiol. Biotechnol. 2010, 88, 965-976. doi:10.1007/s00253-010-2810-1

35. Blom, D.; Fabbri, C.; Eberl, L.; Weisskopf, L. Appl. Environ. Microbiol. 2011, 77, 1000-1008. doi:10.1128/AEM.01968-10

36. Wenke, K.; Weise, T.; Warnke, R.; Valverde, C.; Wanke, D.; Kai, M.; Piechulla, B. Bacterial Volatiles Mediating Information Between Bacteria and Plants. In Bio-Communication in Plants; Witzany, G.; Baluska, F., Eds.; Signaling and Communication in Plants, Vol. 14; Springer: Berlin, 2012; pp 327-347. doi:10.1007/978-3-642-23524-5

37. Ryan, R. P.; Dow, J. M. Microbiology (Reading, U. K.) 2008, 154, 1845-1858. doi:10.1099/mic.0.2008/017871-0
38. Katritzky, A. R.; Chen, K. Anal. Chem. 2000, 72, 101-109. doi:10.1021/ac990800w

39. Schulz, S. Lipids 2001, 36, 637-647. doi:10.1007/s11745-001-0768-7

40. Junkes, B. S.; Amboni, R. D. M. C.; Heinzen, V. E. F.; Yunes, R. A. Chromatographia 2002, 55, 707-713. doi:10.1007/BF02491786

41. Bruce, A.; Verrall, S.; Hackett, C. A.; Wheatley, R. E. Holzforschung 2004, 58, 193-198. doi:10.1515/HF.2004.029

42. Höckelmann, C.; Moens, T.; Jüttner, F. Limnol. Oceanogr. 2004, 49, 1809-1819. doi:10.4319/lo.2004.49.5.1809

43. Tressl, R.; Friese, L. Z. Lebensm.-Unters. Forsch. 1978, 166, 350-354. doi:10.1007/BF01181504

44. Joulain, D.; Laurent, R.; Fourniol, Y. P.; Yaacob, K. B. J. Essent. Oil Res. 1991, 3, 355-357.

45. Schlumpberger, B. O.; Clery, R. A.; Barthlott, W. Plant Biol. 2006, 8, 265-270. doi:10.1055/s-2005-873045

46. Altintas, A.; Koca, U.; Demirci, B.; Husnu Can Baser, K. Asian J. Chem. 2010, 22, 4711-4716.

47. Dickschat, J. S.; Bode, H. B.; Wenzel, S. C.; Müller, R.; Schulz, S. ChemBioChem 2005, 6, 2023-2033. doi:10.1002/cbic.200500174

48. Dickschat, J. S.; Helmke, E.; Schulz, S. Chem. Biodiversity 2005, 2, 318-353. doi:10.1002/cbdv.200590014

49. Dickschat, J. S.; Wenzel, S. C.; Bode, H. B.; Müller, R.; Schulz, S. ChemBioChem 2004, 5, 778-787. doi:10.1002/cbic.200300813

50. Francke, W.; Schulz, S. Pheromones. In Miscellaneous Natural Products Including Marine Natural Products, Pheromones, Plant Hormones, and Aspects of Ecology; Barton, D.; Nakanishi, K., Eds.; Comprehensive Natural Products Chemistry, Vol. 8; Elsevier: Amsterdam, 1999; pp 197-261. doi:10.1016/B978-0-08-091283-7.00052-7

51. Papke, M. D.; Riechert, S. E.; Schulz, S. Anim. Behav. 2001, 61, 877-886. doi:10.1006/anbe.2000.1675

52. Bunge, M.; Araghipour, N.; Mikoviny, T.; Dunkl, J.; Schnitzhofer, R.; Hansel, A.; Schinner, F.; Wisthaler, A.; Margesin, R.; Märk, T. D. Appl. Environ. Microbiol. 2008, 74, 2179-2186. doi:10.1128/AEM.02069-07

53. Lindinger, W.; Hansel, A.; Jordan, A. Int. J. Mass Spectrom. Ion Processes 1998, 173, 191-241. doi:10.1016/S0168-1176(97)00281-4

54. Blake, R. S.; Wyche, K. P.; Ellis, A. M.; Monks, P. S. Int. J. Mass Spectrom. 2006, 254, 85-93. doi:10.1016/j.ijms.2006.05.021

55. Knowles, C. J. Bacteriol. Rev. 1976, 40, 652-680.

56. Hunter, E. P. L.; Lias, S. G. J. Phys. Chem. Ref. Data 1998, 27, 413-656. doi:10.1063/1.556018

57. Knighton, W. B.; Fortner, E. C.; Midey, A. J.; Viggiano, A. A.; Herndon, S. C.; Wood, E. C.; Kolb, C. E. Int. J. Mass Spectrom. 2009, 1-3, 112-121. doi:10.1016/j.jjms.2009.02.013

58. Ryan, F. J.; Schneider, L. K. J. Bacteriol. 1947, 54, 209-211.

59. Stall, R. E.; Hall, C. B.; Cook, A. A. Phytopathology 1972, 62, 882-886. doi:10.1094/Phyto-62-882

60. Nijland, R.; Burgess, J. G. Biotechnol. J. 2010, 5, 974-977. doi:10.1002/biot.201000174

61. Bernier, S. P.; Létoffé, S.; Delepierre, M.; Ghigo, J. M. Mol. Microbiol. 2011, 81, 705-716. doi:10.1111/j.1365-2958.2011.07724.x

62. Kai, M.; Piechulla, B. FEBS Lett. 2009, 583, 3473-3477. doi:10.1016/j.febslet.2009.09.053

63. Steeghs, M. M. L.; Crespo, E.; Harren, F. J. M. Int. J. Mass Spectrom. 2007, 263, 204-212. doi:10.1016/j.ijms.2007.02.011 
64. Crespo, E.; Cristescu, S. M.; de Ronde, H.; Kuijper, S.; Kolk, A. H. J.; Anthony, R. M.; Harren, F. J. M. J. Microbiol. Methods 2011, 86, 8-15. doi:10.1016/j.mimet.2011.01.025

65. Bricci, I.; Leitner, M.; Foti, M.; Mithöfer, A.; Boland, W.; Maffei, M. E. Planta 2010, 232, 719-729. doi:10.1007/s00425-010-1203-0

66. Kai, M.; Vespermann, A.; Piechulla, B. Plant Signal. Behav. 2008, 3, 482-484. doi:10.4161/psb.3.7.5681

67. McLafferty, F. W.; Stauffer, D. B. The Wiley/NBS Registry of Mass Spectral Data; Wiley: New York, 1989.

68. Adams, R. P. Identification of Essential Oil Components by Gas Chromatography/Mass Spectometry, 4th ed.; Allured Publ. Corp.: Carol Stream, U.S.A., 2007.

69. Kováts, E. sz. Fresenius' Z. Anal. Chem. 1961, 181, 351-364. doi:10.1007/BF00466597

70. Hansel, A.; Jordan, A.; Holzinger, R.; Prazeller, P.; Vogel, W.; Lindinger, W. Int. J. Mass Spectrom. Ion Processes 1995, 149-150, 609-619. doi:10.1016/0168-1176(95)04294-U

71. de V. Weir, J. B. Nature 1960, 187, 438. doi:10.1038/187438a0

72. Brandsma, L. Preparative Acetylenic Chemistry; Elsevier: Amsterdam, 1988.

73. Corey, E. J.; Schmidt, G. Tetrahedron Lett. 1979, 20, 399-402. doi:10.1016/S0040-4039(01)93515-4

74. Cernecki, S.; Georgoulis, C.; Stevens, C. L.; Vijayakumaran, K. Tetrahedron Lett. 1985, 26, 1699-1702. doi:10.1016/S0040-4039(00)98314-X

75. Sonnet, P. E.; Carney, R. L.; Henrick, C. J. Chem. Ecol. 1985, 11, 1371-1387. doi:10.1007/BF01012138

\section{License and Terms}

This is an Open Access article under the terms of the Creative Commons Attribution License (http://creativecommons.org/licenses/by/2.0), which permits unrestricted use, distribution, and reproduction in any medium, provided the original work is properly cited.

The license is subject to the Beilstein Journal of Organic Chemistry terms and conditions:

(http://www.beilstein-journals.org/bjoc)

The definitive version of this article is the electronic one which can be found at: doi: $10.3762 /$ bjoc. 8.65 